\title{
The Contribution of Nutrients and Water Properties to the Carbonate System in Three Particular Areas of the Tropical Atlantic (NE-BRAZIL)
}

\author{
Leonardo Bertini, Elisabete de Santis Braga* \\ Oceanographic Institute, University of São Paulo, São Paulo, Brazil \\ Email: *edsbraga@usp.br
}

How to cite this paper: Bertini, L., \& Braga, E. S. (2022). The Contribution of $\mathrm{Nu}-$ trients and Water Properties to the Carbonate System in Three Particular Areas of the Tropical Atlantic (NE-BRAZIL). Journal of Geoscience and Environment Protection, 10, 135-161.

https://doi.org/10.4236/gep.2022.102009

Received: January 17, 2022

Accepted: February 25, 2022

Published: February 28, 2022

Copyright $\odot 2022$ by author(s) and Scientific Research Publishing Inc. This work is licensed under the Creative Commons Attribution International License (CC BY 4.0).

http://creativecommons.org/licenses/by/4.0/

\begin{abstract}
Tropical waters show different regional aspects due to specificities in their nutrient biogeochemical cycles, which can affect the carbon system and influence their regional role as sinks or sources of $\mathrm{CO}_{2}$. This study was performed on particular tropical areas that present a different seasonal behaviour related to the carbon cycle observed in the late rainy season (July 2013). Understanding the $\mathrm{CO}_{2}$ drawdown and outgassing potential in these areas is needed to call attention to more long-term monitoring efforts and protect understudied tropical coastal systems more efficiently. This study is focused on nutrient values, hydrological data, biogeochemical carbon behaviour linked to the carbonate system and includes estimates of $\mathrm{CO}_{2}$ fluxes in three contrasting areas off the northeastern Brazilian shelf: 1) an urbanised estuary (Recife-REC), 2) a coastal Island (Itamaracá-ITA) and 3) an oceanic archipelago (Fernando de Noronha-FN). In general, REC acted as a source, while ITA and FN as carbon sinks. In ITA, despite the high DIC and Total Alkalinity observed (mean $\sim 2360 \mu \mathrm{mol} \cdot \mathrm{kg}^{-1}$ ), the sink is associated with an effective cascading of atmospheric $\mathrm{CO}_{2}$ associated with turbulent shallow waters coupled with biogenic removal of $\mathrm{CO}_{3}^{2-}$ and precipitation of $\mathrm{CaCO}_{3}$ by coralline algae. FN acted as a sink, linked to minor decreases in Total Alkalinity (mean 2295 $\mu \mathrm{mol} \cdot \mathrm{kg}^{-1}$ ) influenced by ammonium-based primary production, nitrogen fixation and sporadic entrainment of nutrient rich waters in the upper thermocline. More studies in different western tropical Atlantic coastal systems can improve the knowledge of tropical shelf seas and their contribution to the ocean carbon budget under specific regional trophic regimes.
\end{abstract}




\section{Keywords}

N/P/Si Ratios, Total Alkalinity, $\mathrm{CO}_{2}$ Flux, Dissolved Inorganic Carbon, Trophic Conditions, Western Tropical Atlantic

\section{Introduction}

Recent cumulative $\mathrm{CO}_{2}$ data from Friedlingstein et al. (2019) showed that around $25 \%$ of all anthropogenic carbon emissions (160 $\pm 20 \mathrm{GtC})$ had been taken up by the global ocean since the preindustrial era, i.e. from 1850 and 2019. The same study also showed that the average ocean sink has reduced over the last decade (from 2009 to 2018 ) to approximately $22.5 \%$ of anthropogenic emissions, highlighting the global ocean is losing its capacity to take up and store anthropogenic $\mathrm{CO}_{2}$. As little as the human $\mathrm{CO}_{2}$ footprint might seem (655 \pm 65 $\mathrm{GtC}$ ) compared to the total inventory of oceanic carbon $440,000 \mathrm{GtC}$ (Le Quéré et al., 2015; Ussiri \& Lal, 2017; Friedlingstein et al., 2019), marine ecosystems are already responding to the rise in atmospheric $\mathrm{CO}_{2}$ levels. Increasing trends of acidification in the surface ocean and worldwide changes in the relative proportions of the chemical species that form the Dissolved Inorganic Carbon pool are being reported (DIC, i.e., the sum of $\left[\mathrm{CO}_{2(\mathrm{aq})}\right],\left[\mathrm{HCO}_{3}^{-}\right]$and $\left[\mathrm{CO}_{3}^{2-}\right]$ ) (Winn et al., 1998; Bates, 2007; Bates et al., 2014).

Due to the dissociation of the carbonate system species, only $\mathrm{CO}_{2(\mathrm{aq})}$ is directly related to air-sea exchange. The other 2 species, bicarbonate and carbonate ions $\left(\mathrm{HCO}_{3}^{-}\right.$and $\mathrm{CO}_{3}^{2-}$, respectively), are proton acceptors and form the major acid-base system controlling seawater total alkalinity (TA) (Wolf-Gladrow et al., 2007). These DIC forms can participate in processes within the ocean, and be transported away from the regions of enhanced gas exchange (such as zones of deep water formation-a carbon sinking process known as the solubility pump), and are eventually removed by chemical precipitation with $\mathrm{Ca}^{2+} / \mathrm{Mg}^{2+}$ or take part in biological processes such as carbon fixation into living tissue and calcification of rigid structures. The biogeochemical processes that remove $\mathrm{C}$ from the DIC pool into other compartments (e.g., particulate matter by assimilation, precipitation, mineralization) form a gradient between the surface and subsurface waters, enabling the action of carbonate and the biological pumps.

However, as more DIC enters the carbonate system due to anthropogenic pressure, $\mathrm{pH}$ lowers as a result of $\mathrm{H}_{2} \mathrm{CO}_{3}$ and $\mathrm{HCO}_{3}^{-}$formation and their dissociations, leading to a decrease in seawater alkalinity by increasing the relative proportions $\mathrm{CO}_{2(\mathrm{aq})}$ and $\mathrm{HCO}_{3}^{-}$, whilst decreasing that of $\mathrm{CO}_{3}^{2-}$ (Doney et al., 2009). These changes in the carbonate system's ionic proportions result in the attenuation of the carbonate pump. This process is further affected by the synergic outgassing caused by sea surface warming, resulting in the weakening of the solubility pump as well. The overall outcome is a carbonate system shifted towards $\mathrm{CO}_{2(\mathrm{aq})}$ formation and increased $\mathrm{pCO}_{2 \mathrm{sw}}$ levels, leading to the global ocean 
losing its buffering and atmospheric $\mathrm{CO}_{2}$ uptake capacities.

The buffering itself can be measured by the Revelle Factor (R), which is the ratio between the relative change in $\mathrm{pCO}_{2 \mathrm{~atm}}$ and the relative change in DIC. It indicates the percentage of increase in $\mathrm{pCO}_{2 \mathrm{~atm}}$ that is necessary to increase DIC by $1 \%$. R usually varies from 8 to 15 , for warm and cold waters respectively (Broecker et al., 1979; Egleston et al., 2010) and is given as:

$$
R=\left(p \mathrm{CO}_{2 \mathrm{~atm}} / p \mathrm{CO}_{2 \mathrm{~atm}}\right) /(\Delta \mathrm{DIC} / \mathrm{DIC})
$$

where:

$\left(\Delta \mathrm{pCO}_{2 \mathrm{~atm}} / \mathrm{pCO}_{2 \mathrm{~atm}}\right)$ is the instantaneous change in $\mathrm{pCO}_{2 \mathrm{~atm}}$.

( $\triangle \mathrm{DICDIC}$ ) is the instantaneous change in DIC.

Changes in $\mathrm{CO}_{2}$ solubility linked to acidification and sea surface warming can also have cascading effects on calcification rates of marine calcifiers (Hutchins et al., 2007; Riebesell et al., 2000). The reduced contribution of $\mathrm{CO}_{3}^{2-}$ to the DIC pool causes the shallowing of the lysocline (depth at which the aragonite saturation state- $\Omega_{\mathrm{ar}}$-equals 1 ), resulting in habitat loss for mesopelagic calcifiers. $\Omega_{\mathrm{ar}}$ decreased on average $20 \%$ since the Industrial Revolution and was chosen as a threshold parameter for ocean acidification when a study by Rockström et al. (2009) defined planetary boundaries that, once trespassed, are not likely to be recovered. $\Omega_{\text {ar }}$ is given as:

$$
\Omega_{\mathrm{ar}}=\left[\mathrm{Ca}^{2+}\right]\left[\mathrm{CO}_{3}^{2-}\right] / \mathrm{Ksp}_{\mathrm{ar}}
$$

where:

$\Omega_{\mathrm{ar}}$ is the aragonite saturation state.

$\left[\mathrm{Ca}^{2+}\right]$ and $\left[\mathrm{CO}_{3}^{2-}\right]$ are the concentrations of calcium and carbonate ions.

$K s p_{a r}$ is the solubility product constant for aragonite, which increases with increasing pressure and decreasing temperature.

Despite the broad consensus of how the excess of atmospheric $\mathrm{CO}_{2}$ is impacting the oceans, little is known as to how specific marine systems are responding to such pressures in terms of local imbalances in the carbonate system and nutrient biogeochemical shifts. Regarding tropical regions, especially the Tropical Western Atlantic, regional observational studies regarding their role in the ocean carbon cycle are scarce. According to Schuster and Gruber (2012), the Equatorial Atlantic is a source of about $0.12 \pm 0.04 \mathrm{Pg} \mathrm{C} \cdot \mathrm{yr}^{-1}$ to the atmosphere, agreeing with other studies that show the Tropical Atlantic is a source of $\mathrm{CO}_{2}$ (Oudot et al., 1995; Takahashi et al., 2002; Takahashi et al., 2009; Landschützer et al., 2014). However, Schuster and Gruber (2012) highlight that their outgassing estimate is inferior to what it used to be during pre-industrial times, when it was twice as large. Results from Goyet et al. (1998) suggest that the superficial layers of the Tropical Atlantic have become weaker sources of $\mathrm{CO}_{2}$ to the atmosphere. This decrease in the Equatorial Atlantic $\mathrm{CO}_{2}$ outgassing is mainly attributed to the counteracting effect of anthropogenic $\mathrm{CO}_{2}$ uptake by the Tropical Atlantic as described by Gruber et al. (2009).

While most studies suggest the Equatorial and Tropical Atlantic as overall 
$\mathrm{CO}_{2}$ sources, recent studies show that the atmospheric balance can be shifted towards $\mathrm{CO}_{2}$ uptake at regional scales due to particularities with respect to ocean circulation, significant freshwater inputs and salinity-driven subsidence of seawater parcels. A few examples include the Amazon River plume (Ternon et al., 2000; Körtzinger, 2003; Cooley \& Yager, 2006; Cooley et al., 2007; Lefévre et al., 2017), the subsidence of highly-saline (i.e. dense) lenses formed by increased evaporation (de Souza et al., 2013) as well as precipitation regimes which are associated with the migration of the Intertropical Convergence Zone (ITCZ) (Bonou et al., 2016). Furthermore, a recent study using $\mathrm{pCO}_{2}$ trends has also highlighted how equatorial sectors of the Atlantic off north and northeastern Brazil are prone to shift towards $\mathrm{CO}_{2}$ sink in areas far from the influence of the Amazon plume (Araujo et al., 2019).

Despite the increasing amount of evidence showing tropical seas as potential seasonal sinks of anthropogenic $\mathrm{CO}_{2}$ and the fact that these areas are one of the most biogeochemically active in the oceans, regional estimates of $\mathrm{CO}_{2}$ flux remain limited and bound to studies based on large-scale modelling approaches. This includes the northeastern Brazilian coast and its overlooked wide range of tropical ecosystems such as estuaries, mangroves, tidal plains, coral reefs, and shallow calcareous algae banks. There is still great uncertainty as to what extent these environments can buffer increasing atmospheric $\mathrm{CO}_{2}$ levels and their role in the atmospheric $\mathrm{CO}_{2}$ sink. Regional-scale studies in this part of the Atlantic are increasingly important to bridge the gaps and fine-tune large-scale modelling approaches, as well as improve our understanding of how the carbonate system and $\mathrm{CO}_{2}$ flux are mediated by nutrient cycling and trophic regimes while also responding to anthropogenic activity and the associated impacts on the overall carbon budget.

This study is based on assessing the carbonate system and the associated nutrient biogeochemical processes in three distinct regions off northeastern Brazil. The overall goal was to test whether shelf regions off northeastern Brazil are distinct enough to not be treated homogeneously in studies looking at meso and large-scale anthropogenic $\mathrm{CO}_{2}$ retention in the Tropical South Atlantic, due to their seasonal biogeochemical and trophic regimes. These contrasting areas were chosen to represent marine ecosystems that are found along the northeastern Brazilian coast and included: an urbanized estuarine metropolitan region (Recife-REC), a coastal island (Itamaracá-ITA) and a pristine oceanic archipelago (Fernando de Noronha-FN). Focus is given to differences in terms of nutrient data, $\mathrm{CO}_{2}$ buffering capacities, $\Omega$ ar and estimates of $\mathrm{CO}_{2}$ flux during the end of the rainy season in July of 2013.

\section{Study Areas}

Fernando de Noronha (FN) is an oceanic archipelago $550 \mathrm{Km}$ off Recife, in the Equatorial Atlantic (Figure 1(a) \& Figure 1(b)). The area comprises a Marine Park around its main island and is delimited by the $50 \mathrm{~m}$ isobath. The archipe- 
lago belongs to one of the western branches of the Mid-Atlantic Ridge (Gomes et al., 2000; Almeida, 2007) and is composed of 21 islands, covering an area of 113 $\mathrm{km}^{2}$. In FN, the population density is 170 inhabitants $\cdot \mathrm{km}^{-2}$ (IBGE, 2015a) and occupation is restricted to $35 \%$ of the main island, where population and tourist numbers are controlled. The FN region is surrounded by coral reefs with relatively warmer water, where evaporation exceeds precipitation throughout the year. The ocean dynamics around FN is influenced by circulation patterns in the Equatorial Atlantic, mainly controlled by large-scale variability in trade winds and the migration of the Intertropical Convergence Zone (ITCZ) (Lumpkin \& Garzoli, 2005). The South Equatorial Current (SEC) flows westward and brings relatively high salinity and high temperature waters to FN at surface (S 36 and $\mathrm{T} \sim 28^{\circ} \mathrm{C}$ ) while, underneath, between $150-350 \mathrm{~m}$ deep and flowing the opposite direction, the South Equatorial Undercurrent (SEUC) can be found between $3^{\circ} \mathrm{S}$ - $5^{\circ} \mathrm{S}$, which is an eastward branch of the western boundary undercurrent known as North Brazil Undercurrent (NBUC) (Figure 4(c)). The SEUC maximum geostrophic velocities have been estimated at $25^{\circ} \mathrm{W}-28^{\circ} \mathrm{W}$ ranging from $20-40$ $\mathrm{cm} \cdot \mathrm{s}^{-1}$ with its nucleus at about $150 \mathrm{~m}$ deep (Marin, 2009; Schott et al., 2002). Across the $35^{\circ} \mathrm{W}$ meridian and closer to the location of FN, the SEUC flow was detected as deep as $\sim 400 \mathrm{~m}$ with (Arhan et al., 1998; Schott et al., 2005). The Archipelago is an oasis to many migratory species, it is one of the main nesting grounds for marine birds in the entire Atlantic Ocean. The archipelago is partially protected as a no-take MPA and recognized by the UNESCO as a World Heritage Site. It also represents the only Brazilian oceanic island with a large permanent human population (3000 people), mass tourism (up to 90,000 people per year) and a permanent small-scale fishing community (Matheus et al., 2019).

Itamaracá Island (ITA) is a coastal island located $56 \mathrm{~km}$ north of Recife (Figure 1(c)) with a population density of 370 inhabitants. $\mathrm{km}^{-2}$ (IBGE, 2015b). In front of the Island, the continental shelf is approximately $39 \mathrm{~km}$ wide with a maximum depth of $50 \mathrm{~m}$ (Araújo et al., 2004). There are no significant riverine inputs and its coast is characterized by a shallow water column with seagrasses, Halodule wrightii, thriving closer to the shore and calcareous algae banks of $L i$ thothamnium $s p$ and Halimeda $s p$ covering the sea bed from the $15 \mathrm{~m}$ isobath and deeper. In its shallow waters, the expected pattern is a higher productivity at higher irradiance levels, as demonstrated for another species of Lithothamnium, which had a $70 \%$ reduction in its productivity when submitted to a $30 \%$ reduction in incident light, about $30 \mu \mathrm{mol}$ photons $\cdot \mathrm{m}^{-2} \cdot \mathrm{s}^{-1}$ (Riul et al., 2008). In fact, other calcareous algae that form rhodoliths or cover coastal reefs in shallow waters are more productive at higher irradiance levels, around $100 \mu \mathrm{mol}$ photons $\mathrm{m}^{2} \cdot \mathrm{s}^{-1}$ (Villas-Boas et al., 2005). Rhodolith beds, like many other marine ecosystems, are affected by ongoing global change due to the increase in greenhouse gases in the atmosphere $\left(\mathrm{CO}_{2}\right.$ in particular) and all its associated consequences, such as increases in seawater temperatures $\left(1^{\circ} \mathrm{C}-4^{\circ} \mathrm{C}\right.$ by 2100$)$, decreases in seawater $\mathrm{pH}$ (by $\sim 0.3-0.5$ units), shifts in carbon chemistry, sea level rise, and 
the increase in strength and frequency of extreme weather events (Gibbard et al., 2005; IPCC, 2014).

Recife (REC) is the main urban centre in northeastern Brazil. It is the 6th most populated metropolitan region, reaching a population density of 1400 inhabitants $\mathrm{km}^{-2}$ (IBGE, 2015c) (Figure 1 (d)). The region lies partly on the mainland and partly on an island, thus being crossed by a series of waterways and connected by bridges. It is an area of great environmental and socio-economic importance in terms of shipping activity and fisheries. The water bodies flowing through REC, especially the Capibaribe and Beberibe rivers, are heavily polluted due to the dumping of domestic and industrial effluents and shipping traffic. According to the Pernambuco State Water Resources Agency, at the Capibaribe river mouth, eutrophic waters are found with $\mathrm{DO}$ values reaching $0 \mathrm{~mL} \cdot \mathrm{L}^{-1}$ and elevated values of ammonium, phosphate and thermo-tolerant coliforms (CPRH-PE, 2012). The continental shelf of REC is approximately $37 \mathrm{~km}$ wide, with a maximum depth of $65 \mathrm{~m}$ (Araújo et al., 2004). Sandstone reefs are found along the coast, protecting the shoreline in the event of surges. However, these reefs have lost their size and biodiversity over time, due to eutrophication, increase in turbidity caused by the penetration of the river plume, ocean acidification and human activities (Flores Montes et al., 2011).

\section{Material and Methods}

\subsection{Sampling}

Due to its tropical character, temperatures along the northeastern Brazilian coast do not vary significantly, with precipitation being the main factor responsible for determining the two main seasons: rainy and dry. Our study was carried out in the late rainy season, in July of 2013. In FN, one station was done off its south side (station 14) and two stations off its north side (stations 15 and 16), comprising an area of approximately $100 \mathrm{Km}^{2}$ (Figure $1(\mathrm{~b})$ ). At least five depths were sampled at each station. On the way to FN, an additional single oceanographic station was done in the open ocean (depth $>4000 \mathrm{~m}$ ) southeast off FN, nearly halfway from ITA, where the deepest sampling was done, with ten sampled depths, the deepest at $500 \mathrm{~m}$ (Figure 1(a)). In ITA, seawater sampling was carried out along its shelf, one satiation down south (Station 10) and other two up north (stations 11 and 12), with at least three sampled depths at each one, comprising an area of approximately $36 \mathrm{Km}^{2}$ (Figure $1(\mathrm{c})$ ). In REC there were nine oceanographic stations (stations 1 - 9), most of them with at least three sampled depths, comprising an area of approximately $28 \mathrm{Km}^{2}$ in front of the Port of Recife, which is also where the Capibaribe River meets the ocean (Figure $1(d)$ ). See Table 1 for detailed information on all stations and sampled depths.

\subsection{Seawater Chemical Analyses}

Seawater was collected aboard R/V Alpha Delphini (Oceanographic Institute of the University of São Paulo) during its inaugural oceanographic campaign using 


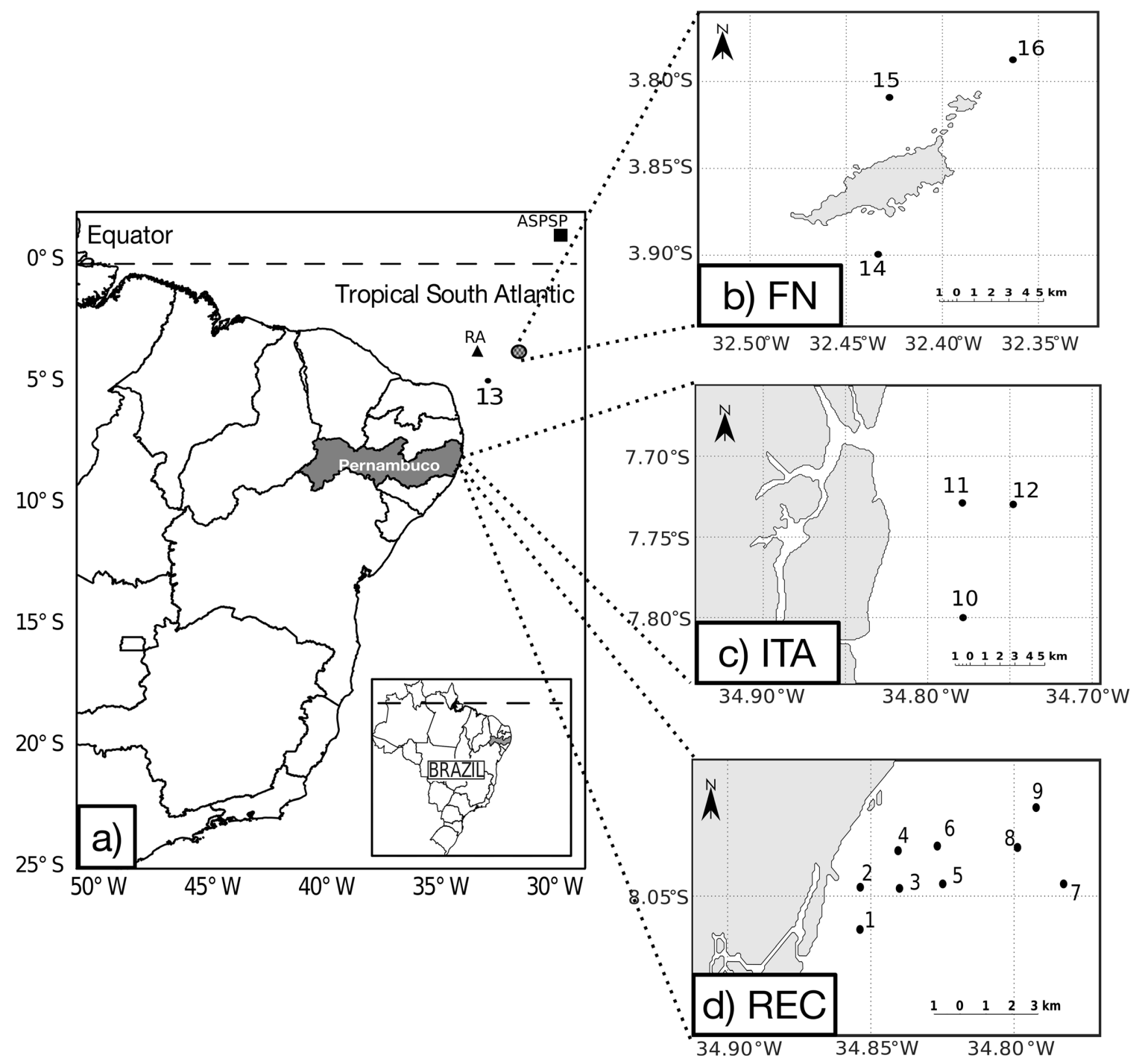

Figure 1. (a) The position of station 13; zoomed-in views of (b) the Fernando de Noronha Archipelago (FN) (Stations 14 - 16); (c) Itamaracá Island (ITA) (Stations 10 - 12) and (d) the inner continental shelf of Recife (REC) (Stations 1 - 9) off the coast of Pernambuco state. The relative locations of the Rocas Atoll (RA) and the Archipelago of Saint Peter and Saint Paul (ASPSP) are also shown in panel (a).

a Seabird ${ }^{\circledR}$ rosette with 12-bottles and a CTD module attached (model SBE 19 plus). Seawater temperature was retrieved from the CTD $\left( \pm 0.001^{\circ} \mathrm{C}\right)$. Salinity determination was conducted using a Beckman ${ }^{\circledR}$ RS-10 salinometer $( \pm 0.001)$ and the Dissolved Oxygen concentration (DO) was determined by potentiometric determination using al Titrando, Metrohm ${ }^{\circledR}$, with precisions of $\pm 0.02 \mathrm{~mL} \cdot \mathrm{L}^{-1}$ for levels up to $2 \mathrm{~mL} \cdot \mathrm{L}^{-1}$ and $\pm 0.04 \mathrm{~mL} \cdot \mathrm{L}^{-1}$ for higher levels, following the recommendations of Grasshoff et al. (1999). The $\mathrm{pH}$ was measured in the total scale using a portable combined glass electrode (model PHM 203) in a Thermo Orion pH meter model P-210A Radiometer ${ }^{\circledR}$, calibrated with standard buffers and stored in a $\mathrm{KCl}$ solution, following Aminot and Chaussepied (1983) and the recommendations of Dickson et al. (2007) with a precision of \pm 0.001 .

Seawater for dissolved nutrients analysis was filtered through $0.45 \mu \mathrm{m} \mathrm{GF} / \mathrm{F}$ 
Table 1. Location and sampled depths of all oceanographic stations along the northeastern coast of Brazil. (Western Tropical South Atlantic, late rainy season, July 2013).

\begin{tabular}{|c|c|c|c|c|}
\hline Study Region & Station & Lat. $\left(^{\circ}\right)$ & Long. $\left(^{\circ}\right)$ & Sampled depths (m) \\
\hline \multirow{9}{*}{ REC } & 1 & -8.05952 & -34.85380 & $0,5,8$ \\
\hline & 2 & -8.04645 & -34.78270 & $0,5,10,15$ \\
\hline & 3 & -8.04645 & -34.82490 & $0,5,8$ \\
\hline & 4 & -8.04775 & -34.84000 & $0,5,8$ \\
\hline & 5 & -8.03692 & -34.84050 & $0,5,8$ \\
\hline & 6 & -8.03600 & -34.79880 & $0,5,10$ \\
\hline & 7 & -8.02453 & -34.79230 & $0,5,10,15$ \\
\hline & 8 & -8.03558 & -34.82680 & $0,5,8$ \\
\hline & 9 & -8.04742 & -34.85370 & 0,5 \\
\hline \multirow{3}{*}{ ITA } & 10 & -7.72890 & -34.77890 & $0,5,10$ \\
\hline & 11 & -7.72980 & -34.74800 & $0,5,10,15$ \\
\hline & 12 & -7.80000 & -34.77850 & $0,5,10$ \\
\hline \multirow[t]{2}{*}{ OPEN OCEAN } & 13 & -5.00410 & -33.15000 & $\begin{array}{c}0,5,10,25,50,75,100 \\
200,300,500\end{array}$ \\
\hline & 14 & -3.89950 & -32.43340 & $0,5,10,15,25,50$ \\
\hline \multirow[t]{2}{*}{ FN } & 15 & -3.80910 & -32.42750 & $0,5,10,15,25$ \\
\hline & 16 & -3.78750 & -32.36330 & $0,5,10,15,25,40$ \\
\hline
\end{tabular}

Whatman ${ }^{\circledR}$ glass fiber membranes and kept frozen at $-20^{\circ} \mathrm{C}$ before chemical analyses. Dissolved silicate $\left(\mathrm{Si}-\mathrm{Si}(\mathrm{OH})_{4}\right)$ and dissolved phosphate $\left(\mathrm{P}^{-} \mathrm{PO}_{4}^{3-}\right)$ were determined by the colorimetric method described by Grasshoff et al. (1999). The absorbance was measured using a Genesis II Bauch \& Lomb ${ }^{\circledR}$ digital spectrophotometer and precisions were $\pm 0.01 \mu \mathrm{mol} \cdot \mathrm{L}^{-1}$ and $\pm 0.02 \mu \mathrm{mol} \cdot \mathrm{L}^{-1}$, respectively. Dissolved inorganic nitrogen (DIN) was obtained from the sum of $\mathrm{N}$-ammonium, $\mathrm{N}$-nitrite and $\mathrm{N}$-nitrate. $\mathrm{N}$-ammonium was determined by the colorimetric method as described by Solorzano (1969) with the proposed adaptations by Tréguer and Le Corre (1975). The absorbance was read at $630 \mathrm{~nm}$ using a Genesis II Bauch \& Lomb ${ }^{\circledR}$ digital spectrophotometer with a precision of $\pm 0.05 \mu \mathrm{M}$. Dissolved nitrite and nitrate were determined as described by Tréguer and Le Corre (1975). The analysis was determined in a continuous flux system using a Bran-Luebbe ${ }^{\circledR}$ AutoAnalyser II, following recommendations proposed by Grasshoff et al. (1999), Tréguer and Le Corre (1975) and Braga (1997a, 1997b) with precisions for nitrite and nitrate of $\pm 0.01 \mu \mathrm{M}$ and $\pm 0.02 \mu \mathrm{M}$, respectively.

Total Alkalinity (TA) analysis was carried out by an open-cell potentiometric titration with a solution of $0.01 \mathrm{M} \mathrm{HCl}$ in $\mathrm{NaCl}$ media to account for seawater ionic strength and to ensure stable activity coefficients (Dickson et al., 2007). Titrations were performed using a Methrom ${ }^{\circledR}$ Dosimat 700 doser, a Methrom ${ }^{\circledR} 827$ 
pH lab and a Methrom ${ }^{\circledR}$ Unitrode glass electrode. The titrant solution was calibrated using an ultrapure TRIS primary standard solution following the recommendations of Grasshoff et al. (1999) and a SRM 423 reference. This method is cost-effective while also maintaining uncertainties at acceptable levels of $1.5 \%$ (Anes et al., 2018). Readings of $\mathrm{pH}$, electric potential and temperature of seawater samples were obtained throughout the titration in a temperature-controlled dark chamber and then used to determine the equivalence volume (Veq) on a Gran plot based on inflexion points. The seawater density was calculated from $\mathrm{T}$ and S using the seawater state equation (UNESCO, 1981) and TA was calculated in gravimetric units of $\mu \mathrm{mol} \cdot \mathrm{kg}^{-1}$.

Seawater samples for Chlorophyll-a (Chl-a) determination were filtered in $0.45 \mu \mathrm{m} \mathrm{GF} / \mathrm{F}$ Whatman ${ }^{\circledR}$ glass fiber membranes. Chl-a was extracted from the filters using a $90 \%$ acetone solution and concentrations were determined by spectrophotometry as recommended by Strickland and Parsons (1972), using a Genesis II Bauch \& Lomb $^{\circledR}$ digital spectrophotometer, with a precision of \pm 0.01 $\mathrm{mg} \cdot \mathrm{m}^{3}$. Seawater samples for dissolved Calcium $\left(\mathrm{Ca}^{2+}\right)$ were also filtered using $0.45 \mu \mathrm{m} \mathrm{GF} / \mathrm{F}$ Whatman ${ }^{\circledR}$ glass fiber membranes and the $\mathrm{Ca}^{2+}$ concentration was determined by chelatometric titration using EDTA following Grasshoff et al. (1999) with a precision of $\pm 2 \mathrm{mg} \cdot \mathrm{L}^{-1}$.

\subsection{Carbonate System and $\mathrm{CO}_{2}$ Flux}

The parameters of the carbonate system were estimated using $\mathrm{CO}_{2}$ calc (Robbins et al., 2010), in which the inputs were $\mathrm{pH}$ and TA, along with pressure, salinity and dissolved nutrients. The set of equilibrium constants used was the one proposed by Millero (2010) for the $\mathrm{CO}_{2}$ species, Dickson (1990) for the silicic acid and Lee et al. (2000) for total boron. Values of DIC, $\mathrm{pCO}_{2} \mathrm{sw}, \mathrm{R}, \Omega_{\mathrm{ar}}$ and $\mathrm{CO}_{2}$ flux were generated by the software. The atmospheric partial pressure of $\mathrm{CO}_{2}$ was required $\left(\mathrm{pCO}_{2 \text { atm }}\right)$ as an input along with wind speed to obtain the air-sea $\mathrm{CO}_{2}$ flux $\left(\mathrm{CO}_{2}\right.$ flux). The $\mathrm{pCO}_{2 \text { atm }}$ was estimated as follows:

$$
p \mathrm{CO}_{2 \text { atm }}=\mathrm{CO}_{2 \text { mixing ratio }} \times\left(P_{\text {atm }}-P_{\text {vapor }}\right)
$$

where: the $\mathrm{CO}_{2}$ mixing ratio is the relative concentration of $\mathrm{CO}_{2}$ in the atmosphere, $\mathrm{P}_{\mathrm{atm}}$ is the atmospheric pressure at sea level and $\mathrm{P}_{\text {vapor }}$ is the water vapor pressure.

The atmospheric $\mathrm{CO}_{2}$ mixing ratio $\left(\mathrm{CO}_{2 \text { mixing ratio }}\right)$ was set at $393 \mathrm{ppm}$, which represents the $20 \mathrm{~m}$-high averaged atmospheric $\mathrm{CO}_{2}$ concentration obtained from the time series record for the city of Natal, the closest to REC at the time of sampling, approximately $250 \mathrm{Km}$ away (NOOA/ESRL in: Dlugokencky et al. (2015)) (Figure 2). Values of atmospheric pressure $\left(\mathrm{P}_{\mathrm{atm}}\right)$ and wind speed were obtained from the meteorological station of R/V Alpha Delphini. The negative contribution of water vapor pressure $\left(\mathrm{P}_{\text {vapor }}\right)$ was calculated according to Weiss and Price (1980).

\subsection{Data Analysis}

The data were processed using the Grubb's test (significance level $\alpha=0.05$ ) and 


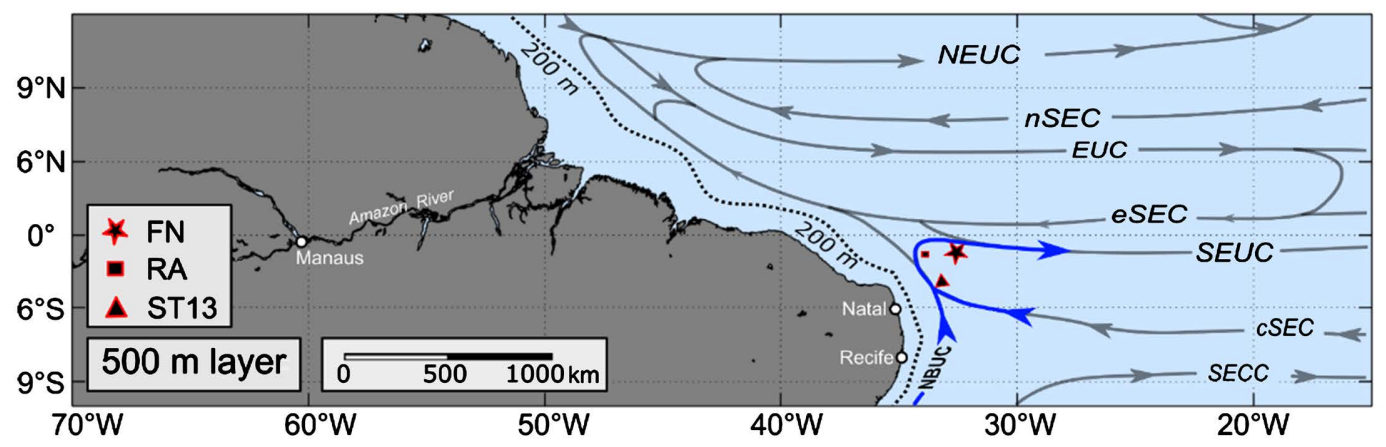

Figure 2. Map of the Central Water layer (100 - $500 \mathrm{~m}$ deep) adapted from Stramma and Schott (1999). The arrows denote the main underwater currents occurring within the CW layer in the Tropical Atlantic. Highlighted in blue are the North Brazil Undercurrent (NBUC), the central South Equatorial Current (cSEC) and the South Equatorial Undercurrent (SEUC). The triangle $(\boldsymbol{\Delta})$, the square $(\boldsymbol{\square})$ and the star $(\star)$ represent the locations of Station 13, the Rocas Atoll, and Fernando de Noronha respectively.

the outliers were removed. Statistical treatment was applied to the dataset by conducting a one-way ANOVA $(\alpha=0.05)$ to parameters that followed normal distribution, which was checked previously via Anderson-Darling probability plots $(\alpha=0.05)$. If differences in the means were statistically significant, Tukey tests were applied to identify significant pair-wise differences. $\mathrm{R}$ version 3.5.3 was used to perform statistical analyses and to generate Box-Whisker plots.

\section{Results and Discussion}

\subsection{Biogeochemistry and the Carbonate System}

\section{Recife (REC)-Coastal Waters}

The largest range of $\mathrm{T}$ and $\mathrm{S}$ was found in REC $\left(25.46^{\circ} \mathrm{C}-27.08^{\circ} \mathrm{C}\right.$ and $33.93^{\circ} \mathrm{C}$ - $36.49^{\circ} \mathrm{C}$, respectively). REC was also the region where the lowest values of $\mathrm{S}$ were registered $(<35)$ (Figure $3(a)$ and Figure $3(b))$. This is common in an environment where river inputs are constant, forming a salinity gradient of distribution. Santiago et al. (2010) detected values much lower in samples collected 4 $\mathrm{km}$ upstream the channel of the Recife port, where the riverine influence is even greater than in the river mouth (S maxima $\sim 9.50$ ). This riverine salinity clearly has an influence on the components of the carbonate system, however it is still unclear to which extent in REC when compared to S-driven fluctuations registered by studies on other impacted tropical estuaries, such as in the estuaries of the Yangtze by Zhai et al. (2007) and the Pearl River estuary, as showed by Guo et al. (2008).

In REC, $\mathrm{pH}$ variability was the highest $(8.08$ - 8.20) in relation to ITA and FN (Figure $3(c)$ ), reef and open ocean areas respectively. The lowest limit highlights the interplay between the intrusion of seawater into the estuarine system and ebb flow carrying continental runoff. In addition to the riverine input in REC, the relatively low $\mathrm{pH}$ values might also result from ammonium-rich sewage discharge and excessive remineralization of organic matter from the metropolitan area (Braga et al., 2018a). N-ammonium comprised the major fraction 
a)

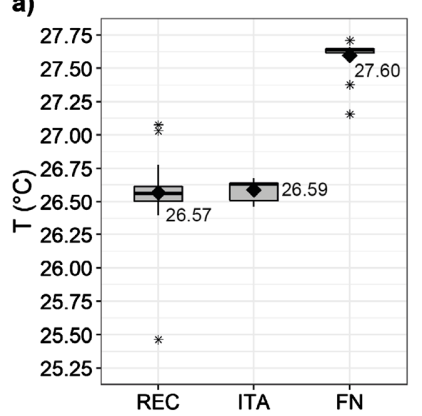

e)

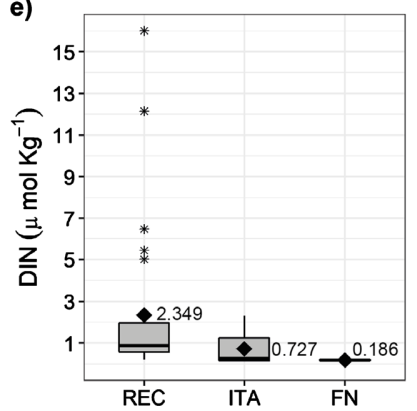

b)

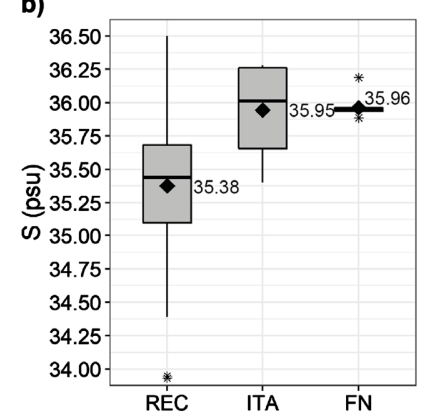

f)

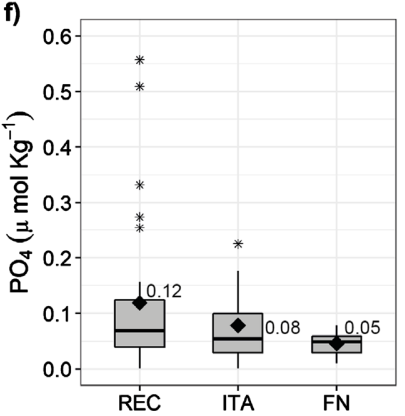

c)

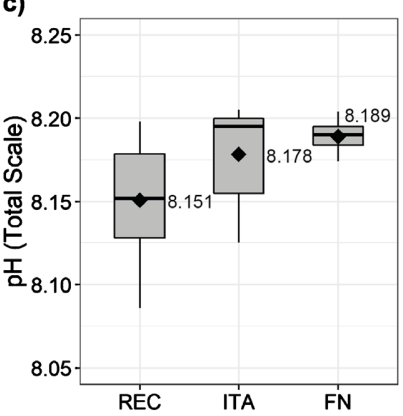

g)

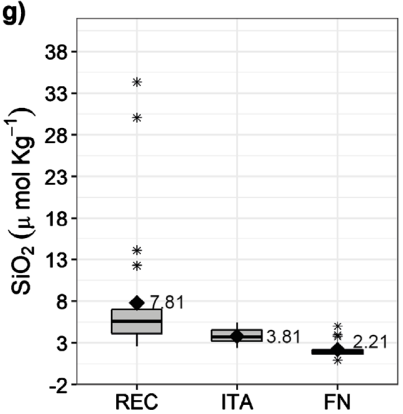

d)

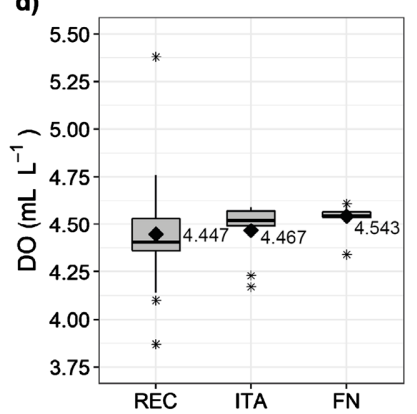

h)

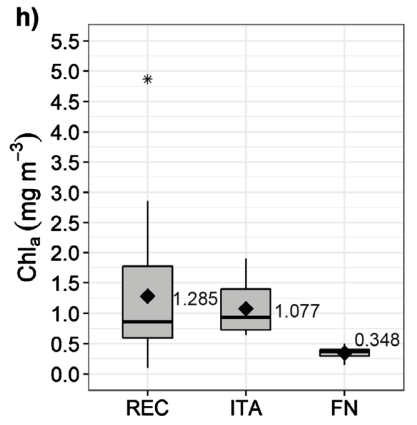

Figure 3. Box-Whisker plots for the biogeochemical parameters at each studied region: (a) $\mathrm{T}\left({ }^{\circ} \mathrm{C}\right)$; (b) $\mathrm{S}$ (psu); (c) $\mathrm{pH}$; (d) $\mathrm{DO}$ $\left(\mathrm{mL} \cdot \mathrm{L}^{-1}\right)$; (e) DIN $\left(\mu \mathrm{mol} \cdot \mathrm{kg}^{-1}\right) ;(\mathrm{f}) \quad \mathrm{P}^{-\mathrm{PO}_{4}^{3-}}\left(\mu \mathrm{mol} \cdot \mathrm{kg}^{-1}\right) ;(\mathrm{g}) \mathrm{Si}-\mathrm{Si}(\mathrm{OH})_{4}\left(\mu \mathrm{mol} \cdot \mathrm{kg}^{-1}\right)$ and $(\mathrm{h}) \mathrm{Chl}-\mathrm{a}\left(\mathrm{mg} \cdot \mathrm{m}^{-3}\right)$. The line represents the median value, the $(\bullet)$ the mean and $\left(^{*}\right)$ the outliers.

of the total DIN pool at the Capibaribe River mouth, where most of the stations registered values higher than $50 \%$.

The intensified remineralization in REC was confirmed by the decreasing DO and Chl-a minima found at the bottom, close to the river mouth $\left(3.87 \mathrm{~mL} \cdot \mathrm{L}^{-1}\right.$ and $0.10 \mathrm{mg} \cdot \mathrm{m}^{-3}$, respectively). On the other hand, at the surface and subsurface levels, specially at station 2, values for DO and Chl-a maxima were respectively $5.38 \mathrm{~mL} \cdot \mathrm{L}^{-1}$ and $4.9 \mathrm{mg} \cdot \mathrm{m}^{-3}$ (Figure $3(\mathrm{~d}$ ) and Figure $3(\mathrm{~h})$ ) showing the positive effect of the nutrient fertilization at the mentioned point, northward.

In terms of total dissolved nutrients, REC showed the highest values associated with the lowest salinities (DIN/ $\mathrm{PO}_{4}^{3-} / \mathrm{Si}(\mathrm{OH})_{4}$ : maxima of $16.10 / 0.58 / 35.91$ $\mu \mathrm{mol} \cdot \mathrm{kg}^{-1}$ ), which is expected from estuarine systems (Figures $3(\mathrm{e})-(\mathrm{g})$ ). Santiago et al. (2010) reported even higher nutrient concentrations inside the mooring area of the port of REC DIN/ $\mathrm{PO}_{4}^{3-} / \mathrm{Si}(\mathrm{OH})_{4}: 59.75 / 16.40 / 133.39 \mu \mathrm{M}$, where riverine influence is pronounced with anthropogenic contribution. This indicates that nutrients are diluted by seawater and consumed on their way out of the port channel, possibly fuelling algal blooms.

In general, Chl-a values in REC were higher than in ITA and FN, with concentrations $>2.00 \mathrm{mg} \cdot \mathrm{m}^{-3}$ (Figure $3(\mathrm{~h})$ ) and increasing closer to the river mouth and towards the surface. Such vertical variability in terms Chl-a as well as DO content in REC can be explained by relatively high photosynthetic activity within the upper layer followed by contribution of pronounced remineralization rates at depth. REC also showed the largest range of $\mathrm{pCO}_{2} \mathrm{sw}(\sim 200 \mu \mathrm{atm})$, with the highest mean $(282 \mu \mathrm{atm})$ and a maximum of $340 \mu \mathrm{atm}$ (Figure 4(c)). Sutton et al. (2019) 

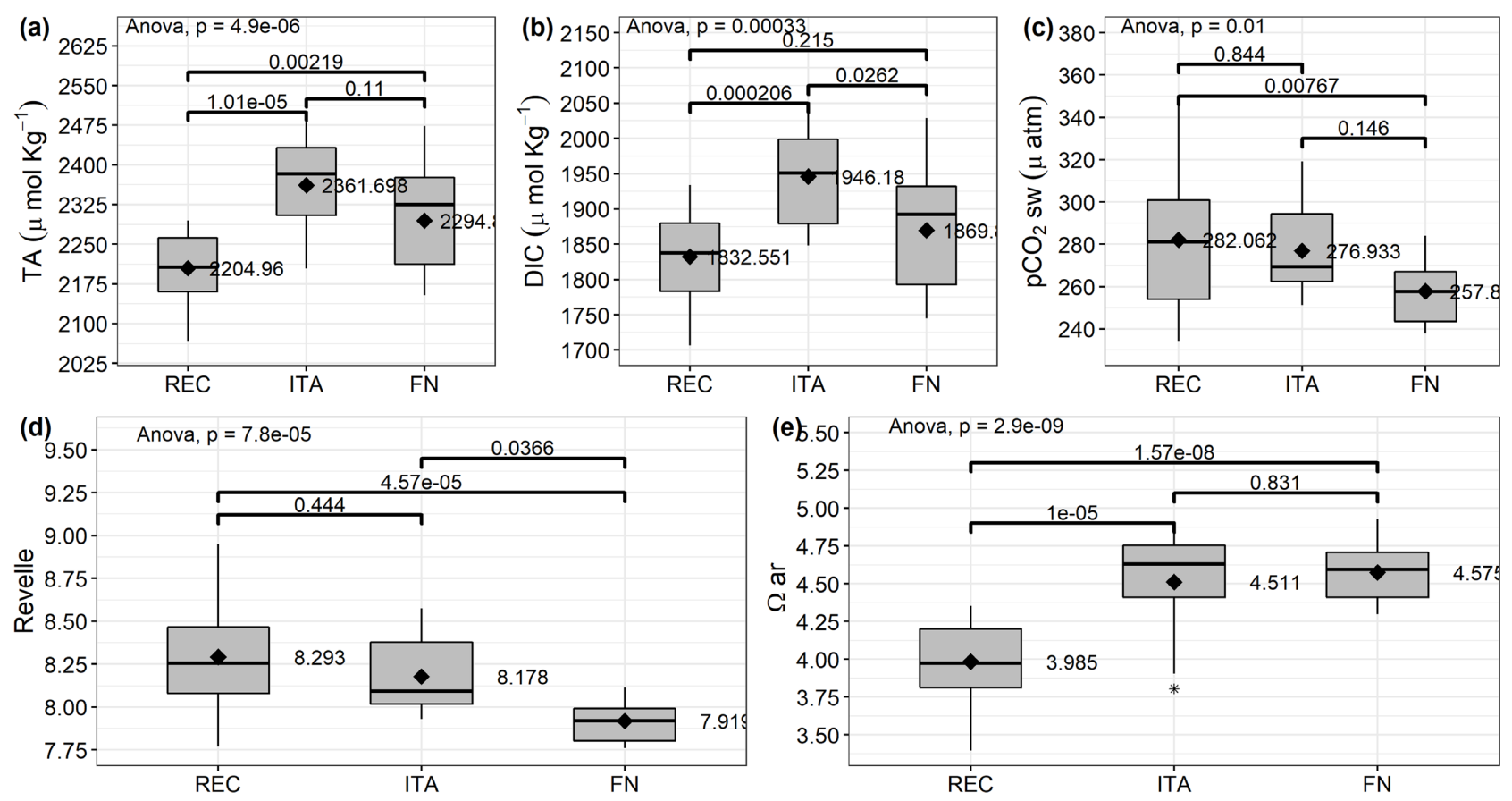

Figure 4. Box-Whisker plots for the carbonate system parameters at each studied region: (a) TA ( $\left.\mu \mathrm{mol} \cdot \mathrm{kg}^{-1}\right)$; (b) DIC ( $\left.\mu \mathrm{mol} \cdot \mathrm{kg}^{-1}\right)$; (c) $\mathrm{pCO}_{2 \mathrm{sw}}$ ( $\left.\mu \mathrm{atm}\right)$; (d) R and (e) $\Omega_{\mathrm{ar}}$. The line represents the median value, the $(\bullet)$ the mean and $\left(^{*}\right.$ ) the outliers. Each panel shows the $p$ value resulting from the one-way ANOVA $(\alpha=0.05)$ and the resulting significances from post-hoc Tukey tests applied to identify pair-wise differences.

reported a range from 60 to $337 \mu \mathrm{atm}$ in coastal areas measured in different mooring locations. The range of results in REC is influenced by freshwater input associated with tidal action on the seafloor associated with the intrusion of remineralized nutrients even under a strong salinity gradient, which contribute to the retention of newly introduced $\mathrm{CO}_{2 \text { (aq) }}$ into the water column and fuels new production locally. Similar correlations were also found by Guo et al. (2008) in the outer estuary of the Pearl River.

Additionally, a relatively high Revelle factor (R) in REC (Figure 4(d)), suggests the water column in this region is less efficient in terms of buffering $\mathrm{pCO}_{2 \text { atm }}$ changes into seawater through an increase in DIC when compared to other two regions studied (ITA and FN). However, it is important to note that the waters studied in REC were twice as efficient when it comes to converting $\mathrm{CO}_{2}$ atm into DIC in relation to other estuarine systems, especially those located in temperate regions, such as the Juan de Fuca Strait studied by Feely et al. (2010), where typically high $\mathrm{R}$ values reached around 15.6.

\section{Itamaracá Island (ITA)-Coastal waters}

Seawater temperatures in ITA, the zone with calcareous benthic community, were the most homogenous, with values ranging from $26.45^{\circ} \mathrm{C}-26.68^{\circ} \mathrm{C}$, while salinity values varied from 35.4 - 36.3, comprising the highest values amongst the studied regions (Figure 3(a) and Figure 3(b)).

DO concentrations in ITA were similar to the values registered in REC and slightly lower when compared to open sea area (FN) (Figure 3(d)). Results for 
dissolved nutrients in ITA showed slightly lower mean values of $\mathrm{DIN} / \mathrm{PO}_{4}^{3-}$ $/ \mathrm{Si}(\mathrm{OH})_{4}: 0.72 / 0.08 / 3.81 \mu \mathrm{mol} \cdot \mathrm{kg}^{-1}$, when compared to the values registered in REC (Figures 3(e)-(g)). Relatively low values of Chl-a (range $0.64-1.90$ $\mathrm{mg} \cdot \mathrm{m}^{-3}$ ) found in ITA indicate productivity partially based on regenerated processes limited by inorganic $\mathrm{N}$ availability.

ITA waters were the most alkaline of the three studied regions, with a TA maximum of $2470 \mu \mathrm{mol} \cdot \mathrm{kg}^{-1}$ (Figure 4 (a)). The relatively high values in ITA can be explained by the higher contribution of dissolved carbonate $\left(\mathrm{CO}_{3}^{2-}\right)$ as a member of carbonate system. This is supported by the relatively high values of $\mathrm{pH}$ as well as by $\Omega_{\mathrm{ar}}$, with slightly higher $\Omega_{\mathrm{a}}$ registered in ITA especially closer to the bottom ( 4.8) followed by FN (4.6, see the next section) and REC (4.0) (Figure $4(e))$.

The $15 \%$ higher TA in ITA is likely to be a result of a series of synergic factors, all of which result in an increase of $\Omega_{\mathrm{ar}}$. An insignificant freshwater input combined with a shallow and well-ventilated water column, as well as slightly higher $\mathrm{T}$ and $\mathrm{S}$ contributed to the reduction of Kspar, while the constant supply of $\mathrm{CO}_{2(\mathrm{aq})}$ from the atmosphere is coupled to an efficient biogenic precipitation, leading to the excess of $\mathrm{Ca}$ ligands (i.e. carbonate ions) with respect to dissolved ionic $\mathrm{Ca}^{2+}$ that is removed from the water column due to the local calcareous algae banks. This is reflected in the mean ratio of dissolved $\mathrm{CO}_{3}^{2-} / \mathrm{Ca}^{2+}$, which was relatively higher in ITA $\left(2.35 \times 10^{-2}\right)$, in relation to $2.06 \times 10^{-2}$ and $2.27 \times$ $10^{-2}$ in REC and FN respectively (Table 2 ).

Table 2. Concentrations of dissolved calcium $\left(\mathrm{Ca}^{2+}\right)$ and carbonate ions $\left(\mathrm{CO}_{3}^{2-}\right)$ and the $\mathrm{CO}_{3}^{2-} / \mathrm{Ca}^{2+}$ ratio at Recife-REC, Itamaracá Island-ITA and Fernando de Noronha-FN. The precision for $\mathrm{Ca}^{2+}$ is $\pm 2 \mathrm{mg} \cdot \mathrm{L}^{-1}$ and for $\mathrm{CO}_{3}^{2-}$ is $\pm 1 \%$ (Grasshoff et al., 1999).

\begin{tabular}{|c|c|c|c|c|c|c|c|}
\hline Study region & Station & $\begin{array}{l}\text { Depth } \\
(\mathrm{m})\end{array}$ & $\begin{array}{c}\mathrm{Ca}^{2+} \\
\left(\mathrm{mg} \cdot \mathrm{L}^{-1}\right)\end{array}$ & $\begin{array}{l}\text { Density } \\
\left(\mathrm{kg} \cdot \mathrm{m}^{-3}\right)\end{array}$ & $\begin{array}{c}\mathrm{Ca}^{2+} \\
\left(\mu \mathrm{mol} \cdot \mathrm{kg}^{-1}\right)\end{array}$ & $\begin{array}{c}\mathrm{CO}_{3}^{2-} \\
\left(\mu \mathrm{mol} \cdot \mathrm{kg}^{-1}\right)\end{array}$ & $\mathrm{CO}_{3}^{2-} / \mathrm{Ca}^{2+}$ \\
\hline \multirow{13}{*}{ REC } & \multirow{3}{*}{1} & 0 & 408.65 & 1022.52 & 9971.880 & 199.13 & 0.0200 \\
\hline & & 5 & 411.97 & 1023.03 & $10,047.92$ & 226.83 & 0.0226 \\
\hline & & 8 & 435.65 & 1023.38 & $10,621.88$ & 189.22 & 0.0178 \\
\hline & \multirow{2}{*}{2} & 0 & 419.50 & 1022.61 & $10,235.63$ & 167.42 & 0.0164 \\
\hline & & 5 & 425.13 & 1023.53 & $10,363.79$ & 188.03 & 0.0181 \\
\hline & \multirow{3}{*}{4} & 0 & 424.41 & 1023.24 & $10,348.98$ & 194.18 & 0.0188 \\
\hline & & 5 & 420.46 & 1023.53 & $10,249.82$ & 208.19 & 0.0203 \\
\hline & & 8 & 426.10 & 1023.63 & $10,386.24$ & 206.00 & 0.0198 \\
\hline & \multirow{3}{*}{5} & 0 & 408.80 & 1022.45 & 9976.110 & 179.53 & 0.0180 \\
\hline & & 5 & 417.45 & 1022.85 & $10,183.20$ & 222.85 & 0.0219 \\
\hline & & 8 & 432.11 & 1023.60 & $10,533.26$ & 192.38 & 0.0183 \\
\hline & \multirow{2}{*}{6} & 0 & 430.23 & 1024.11 & $10,482.23$ & 205.88 & 0.0196 \\
\hline & & 5 & 431.74 & 1024.14 & $10,518.51$ & 229.56 & 0.0218 \\
\hline
\end{tabular}




\section{Continued}

\begin{tabular}{|c|c|c|c|c|c|c|c|}
\hline & & 10 & 430.80 & 1024.48 & $10,492.18$ & 252.09 & 0.0240 \\
\hline & \multirow{4}{*}{7} & 0 & 429.48 & 1024.19 & $10,463.09$ & 235.55 & 0.0225 \\
\hline & & 5 & 434.94 & 1024.25 & $10,595.27$ & 222.32 & 0.0210 \\
\hline & & 10 & 437.00 & 1024.68 & $10,641.25$ & 239.76 & 0.0225 \\
\hline & & 15 & 437.38 & 1024.86 & $10,648.50$ & 222.46 & 0.0209 \\
\hline & \multirow{2}{*}{8} & 0 & 420.83 & 1024.11 & $10,253.15$ & 219.41 & 0.0214 \\
\hline & & 8 & 419.52 & 1024.30 & $10,219.16$ & 236.37 & 0.0231 \\
\hline & \multirow{2}{*}{9} & 0 & 407.70 & 1023.53 & 9938.860 & 225.38 & 0.0227 \\
\hline & & 5 & 424.14 & 1024.00 & $10,334.81$ & 219.40 & 0.0212 \\
\hline \multirow{10}{*}{ ITA } & \multirow{3}{*}{10} & 0 & 430.94 & 1024.43 & $10,496.13$ & 200.08 & 0.0191 \\
\hline & & 5 & 425.65 & 1024.55 & $10,366.04$ & 181.53 & 0.0175 \\
\hline & & 10 & 426.59 & 1024.48 & $10,389.77$ & 232.74 & 0.0224 \\
\hline & \multirow{4}{*}{11} & 0 & 435.28 & 1025.12 & $10,594.84$ & 249.12 & 0.0235 \\
\hline & & 5 & 440.57 & 1025.17 & $10,723.07$ & 269.68 & 0.0251 \\
\hline & & 10 & 431.70 & 1025.22 & $10,506.45$ & 270.78 & 0.0258 \\
\hline & & 15 & 436.80 & 1025.22 & $10,630.52$ & 250.53 & 0.0236 \\
\hline & \multirow{3}{*}{12} & 0 & 434.72 & 1025.11 & $10,581.08$ & 278.88 & 0.0264 \\
\hline & & 5 & 438.44 & 1025.13 & $10,671.41$ & 254.87 & 0.0239 \\
\hline & & 10 & 433.75 & 1025.16 & $10,556.94$ & 288.78 & 0.0274 \\
\hline \multirow{8}{*}{ FN } & \multirow{6}{*}{14} & 0 & 438.81 & 1025.31 & $10,678.72$ & 273.08 & 0.0256 \\
\hline & & 5 & 441.07 & 1025.36 & $10,732.98$ & 260.76 & 0.0243 \\
\hline & & 10 & 438.57 & 1025.37 & $10,672.11$ & 241.21 & 0.0226 \\
\hline & & 15 & 440.46 & 1025.43 & $10,717.54$ & 237.07 & 0.0221 \\
\hline & & 25 & 438.25 & 1025.47 & $10,663.31$ & 227.91 & 0.0214 \\
\hline & & 50 & 439.19 & 1025.77 & $10,683.07$ & 249.66 & 0.0234 \\
\hline & \multirow{2}{*}{15} & 0 & 428.11 & 1025.54 & $10,416.00$ & 214.49 & 0.0206 \\
\hline & & 5 & 431.68 & 1025.58 & $10,502.32$ & 230.43 & 0.0219 \\
\hline
\end{tabular}

Results for $\mathrm{pCO}_{2} \mathrm{sw}$ in ITA showed a narrower range when compared to REC (Figure 4(c)), which reflects its oceanic and more oligotrophic conditions supported by little remineralization of organic matter inducing a new injection CO2aq. Furthermore, the relatively high TA and DIC signals in ITA indicate a water column prone to $\mathrm{CO}_{2(\mathrm{aq})}$ saturation, leading to shifts in the carbonate system towards the formation of $\mathrm{HCO}_{3}^{-}$and $\mathrm{CO}_{3}^{2-}$.

Overall, these results suggest that ITA is the system that sits at the optimal part of the spectrum for $\mathrm{CO}_{2}$ take-up when compared to the other regions investigated. This is mainly attributed to new production and fixation of $\mathrm{C}$ by calcareous algae closely coupled with wind-driven and turbulent mixing in a shallow 
water column, which seem to be the main processes influencing the cascading of atmospheric $\mathrm{CO}_{2}$ (see wind speed record in Figure 5(c)).

\section{Fernando de Noronha (FN)-Oceanic Waters Around the Archipelago}

Seawater temperatures were significantly higher in FN than in ITA and REC (one-way ANOVA, $F(2.52)=143.13, P \leq 0.01$; post-hoc Tukey: $P_{F N-I T A} \leq 0.01$ and $P_{F N-R E C} \leq 0.01$ ), where the warmest waters were found (FN mean temperature of $27.60^{\circ} \mathrm{C}$ ) (Figure $3(\mathrm{a})$ ). This is a result of its equatorial oceanic location, where solar radiation is constant throughout the year. Salinity values in FN were the most homogeneous, with little variation detected across depths and stations (35.90 - 36.15) (Figure 3(b)).

$\mathrm{Chl}-\mathrm{a}$ concentrations were the most homogenous, with values ranging from $0.15-0.50 \mathrm{mg} \cdot \mathrm{m}^{-3}$ (Figure $3(\mathrm{~h})$ ), the lowest between the three studied regions. A study at the Rocas Atoll, located $145 \mathrm{~km}$ east of FN showed a similar range in terms of Chl-a $\left(0.30-1.07 \mathrm{mg} \cdot \mathrm{m}^{-3}\right)$ (Jales et al., 2015). However, de Souza et al. (2013) reported patches of high Chl-a $\left(>0.70 \mathrm{mg} \cdot \mathrm{m}^{-3}\right)$ nearby the archipelago of $\mathrm{FN}$, which might indicate some occasional nuclei of more evident production. In general, the lowest values of dissolved nutrients were found in $\mathrm{FN}$ (DIN/ $\mathrm{PO}_{4}^{3-}$ / $\mathrm{Si}(\mathrm{OH})_{4}$ : maxima of $0.28 / 0.08 / 4.99 \mu \mathrm{mol} \cdot \mathrm{kg}^{-1}$ ) (Figures $3(\mathrm{e})-(\mathrm{g})$ ). The low Chl-a results combined with low dissolved nutrients suggest that primary production is maintained by regenerative processes (i.e., regenerated primary production) and likely supported by nitrogen fixers. A study by Queiroz et al. (2015) on the composition of phytoplankton in the Equatorial Atlantic around the archipelago of Saint Peter and Saint Paul, located $600 \mathrm{~km} \mathrm{NE}$ of FN $\left(0^{\circ} 55^{\prime} 10^{\prime \prime} \mathrm{N}\right.$ $29^{\circ} 20^{\prime} 33^{\prime \prime} \mathrm{W}$-Figure 1(a)) showed that nitrogen fixers (Trichodesmium thiebautii) comprised an important fraction of the phytoplankton biomass in the Equatorial Atlantic.

Studies on the so-called "island mass effect" (IME) have highlighted its role in driving the spatial distribution of Chl-a and nutrients at some parts of the Fernando de Noronha Ridge (FNR) in the Tropical Western Atlantic, such as Jales et al. (2015) and Cordeiro et al. (2013), both studies carried out at the Rocas Atoll, located $145 \mathrm{~km}$ east off FN (Figure 1(a)). Regarding the presence of this effect in FN, de Souza et al. (2013) reported there was evidence of upwelling occurring at seamounts with summits located below the thermocline close to FN. This suggests a topography-flow interaction can occur and disrupt thermohaline structures, consequently causing upward entrainment of deep nutrient-rich water to the top of the thermocline. Even though the intrusion of nutrient-rich water around FN leading to enhanced nutrient assimilation was not investigated in this study. Silva et al. (2019) showed evidence for an uplift of the thermohaline structure during the late rainy season of July 2010, which was associated with an increase of Chl-a concentrations of up to $1 \mathrm{mg} \cdot \mathrm{m}^{-3}$ downstream the Archipelago. However, the same authors highlighted that the observed IME was not strong enough to significantly change the carbonate system to further induce biological carbon uptake or cause a supply of $\mathrm{CO}_{2}$-rich deep waters. 
The obtained results for TA show similar means between FN and ITA (Figure $3(\mathrm{a})$; one-way ANOVA, $F(2,52)=4.44$, post-hoc Tukey: $\left.P_{F N-R E C}=0.11\right)$. However, a larger spread was detected in FN with water tending to be less alkaline (mean TA $2294 \mu \mathrm{mol} \cdot \mathrm{kg}^{-1}$, Figure 4(a)) despite the oceanic character of FN and the lowest variability both in terms of S and $\mathrm{pH}$ (Figure 2(b) \& Figure 2(c)). The lower end values of the TA range $\left(\sim 2150 \mu \mathrm{mol} \cdot \mathrm{kg}^{-1}\right)$ in FN indicate that the carbonate system is partially influenced by other processes associated with the release of hydrogen protons $\left(\mathrm{H}^{+}\right)$within the subsurface layer and the top of the thermocline in $\mathrm{FN}$, consequently reacting with proton acceptors such as $\mathrm{CO}_{3}^{2-}$ and decreasing overall TA values.

Three main processes involving nitrogen fixation at surface levels and a rapid assimilation of nutrients at subsurface levels could help explain the observed mean difference in TA observed between ITA and FN $\left(\Delta \mathrm{TA}\right.$ of $\left.\sim 70 \mu \mathrm{mol} \cdot \mathrm{kg}^{-1}\right)$. The nitrification of recycled nitrogen from $\mathrm{NH}_{4}^{+}$to $\mathrm{NO}_{3}^{-}$followed by rapid $\mathrm{NO}_{3}^{-}$assimilation is responsible for a decrease in TA of 2 moles per mole of $\mathrm{NO}_{3}^{-}$formed. Secondly, the remineralization of newly formed $\mathrm{NH}_{4}^{+}$produced via $\mathrm{N}$ fixation followed by nitrification is responsible for a further decrease in TA of 1 mole per mole of $\mathrm{N}$ fixed. Another process that also reduces TA is the assimilation of $\mathrm{NH}_{4}^{+}$itself, which results in a decrease in TA of 1 mole per mole of $\mathrm{NH}_{4}^{+}$used, following the so-called nutrient- $\mathrm{H}^{+}$-compensation principle (Wolf-Gladrow et al., 2007).

Results for the DIN pool composition in FN show relatively high fractional values of $\mathrm{N}$-ammonium particularly at shallower depths. $\mathrm{NH}_{4}^{+}$comprised more than $60 \%$ of the DIN pool at Station 14 and more than $40 \%$ at Stations 15 and 16 for surface and subsurface depths. Recent studies also show there is enhanced recycling of $\mathrm{NH}_{4}^{+}$associated with productive regimes and a TA drawdown around the main island in FN and close to the shore (Braga et al., 2018a; Braga et al., 2018b).

Furthermore, a quantitative assessment as to whether these nutrient-assimilation mechanisms could have caused such a drawdown is presented based on results shown here and values found in the literature.

Considering nitrification of upwelled $\mathrm{NH}_{4}^{+}$at station 13 and given that the observed mean concentration of $\mathrm{NO}_{3}^{-}$below the thermocline was $\sim 20 \mu \mathrm{mol} \cdot \mathrm{kg}^{-1}$, it is hypothesized that at least $20 \mu \mathrm{mol}$ of recycled $\mathrm{NH}_{4}^{+}$would have been nitrified to $\mathrm{NO}_{3}^{-}$in the upper thermocline and readily assimilated in the oligotrophic water column of $\mathrm{FN}$, producing a $\Delta \mathrm{AT}$ of $\sim 40 \mu \mathrm{mol} \cdot \mathrm{kg}^{-1}$. N fixation estimates in the equatorial South Atlantic are very scarce. However, considering that most studies in the equatorial North Atlantic have estimated the integrated $\mathrm{N}$ fixation at approximately $\sim 200 \mu \mathrm{mol} \mathrm{N} \cdot \mathrm{m}^{-2} \cdot \mathrm{d}^{-1}$ (Gruber \& Sarmiento, 1997; Capone et al., 2005; Moore et al., 2009), values for the upper thermocline in the southern portion of the equatorial Atlantic would likely agree. Therefore, as a first approximation, a $100 \mathrm{~m}$ homogenous upper thermocline in the equatorial South Atlantic would represent a $\Delta \mathrm{AT}$ of $2 \mu \mathrm{mol} \cdot \mathrm{kg}^{-1}$ due to remineralization of fixed $\mathrm{N}$ into $\mathrm{NH}_{4}^{+}$followed by nitrification. Lastly, to account for the total $\Delta \mathrm{AT}$ 
of $\sim 70 \mu \mathrm{mol} \cdot \mathrm{kg}^{-1}$, the direct assimilation of a further $28 \mu \mathrm{mol} \cdot \mathrm{kg}^{-1}$ of remineralised nitrogen in the form of $\mathrm{NH}_{4}^{+}$would have to have occurred. This is plausible given that $\mathrm{NH}_{4}^{+}$constituted a significant part of the DIN pool, which reflects that productivity in FN could also rely on ammonium-based carbon fixation. However, there might be additional contributions driving the observed decrease in TA, which can be, for example, via the release of sulphates during remineralization (Wolf-Gladrow et al., 2007), nevertheless this needs further investigation as the local processes driving the sulphur as well as the nitrogen and carbon cycles in this part of the Atlantic are still poorly understood.

\section{2. $\Delta \mathrm{pCO}_{2}$ and $\mathrm{CO}_{2}$ Flux}

Surface and subsurface $\mathrm{pCO}_{2} \mathrm{sw}$ data from REC showed relatively high values $(>280 \mu \mathrm{atm})$ in front of the Capibaribe river mouth (stations 1 and 2), causing the lower differences between estimated $\mathrm{pCO}_{2 \text { atm }}$ and $\mathrm{pCO}_{2 \text { sw }}(\sim 100 \mu \mathrm{atm})$. These high $\mathrm{pCO}_{2} \mathrm{sw}$ values reflect the role of the river plume in injecting DIC-rich water into the system. Additionally, this coincides with the observed Chl-a maxima at surface levels, showing that this region favours patches of high productivity to develop. In contrast, at stations more offshore (6, 7 and 8) the lowest $\mathrm{pCO}_{2} \mathrm{sw}$ values and the highest differences between estimated $\mathrm{pCO}_{2 \text { atm }}$ and $\mathrm{pCO}_{2 s w}$ were registered $(\sim 180 \mu \mathrm{atm})$. This region of the estuarine system is relatively less dynamic in terms of water movement, which allows for the settlement of organic matter that had been produced at the river mouth. This means that, even with moderate to low primary production levels happening at the surface layers, there is significant remineralization in this portion of the system close to the bottom that drives the observed increase in $\mathrm{pCO}_{2} \mathrm{sw}$. In ITA, $\mathrm{pCO}_{2} \mathrm{sw}$ values ranged from 250 - $300 \mu \mathrm{atm}$. Station 10 showed the maximum value at the surface, followed by station 12 ( $300 \mu \mathrm{atm}$ and $280 \mu \mathrm{atm}$, respectively). These points differed from the estimated $\mathrm{pCO}_{2 \mathrm{~atm}}$ by approximately 80 and $100 \mu \mathrm{atm}$, respectively. Even though, the range of $\mathrm{pCO}_{2} \mathrm{sw}$ observed in REC was larger than that of ITA, no significant difference in mean $\mathrm{pCO}_{2} \mathrm{sw}$ between REC and ITA was found. On the other hand, $\mathrm{pCO}_{2}$ sw values differed significantly between REC and FN, this is mainly due to surface values in FN being significantly lower, highlighting the relatively less saturated and oligotrophic water column of FN (Figure 5(a)).

Overall, $\mathrm{CO}_{2}$ flux estimates suggest that the three regions acted as sinks (negative fluxes) during the sampling campaign in the late rainy season of July 2013 (Figure 5(b)). However, values of $\mathrm{CO}_{2}$ flux from REC were significantly lower than in ITA and FN, with data from stations $1,5,8$ and 9 indicating practically atmospheric equilibrium (fluxes $>-2 \mathrm{mmol} \mathrm{C} \cdot \mathrm{m}^{-2} \cdot \mathrm{d}^{-1}$ ). This suggests that the $\mathrm{CO}_{2}$ flux into the ocean in REC coastal waters is attenuated by high $\mathrm{pCO}_{2} \mathrm{sw}$, which might be a result of the combined effects of eutrophication, remineralization, low $\mathrm{pH}$ and high freshwater and DIC inputs, all of which counteract a further dissolution of $\mathrm{CO}_{2 \text { atm }}$, shifting the carbonate system towards $\mathrm{CO}_{2 \text { (aq) }}$ formation and outgassing. Most studies concerning $\mathrm{CO}_{2}$ fluxes in estuarine systems along the Brazilian northeastern coast show that these systems typically act sources of $\mathrm{CO}_{2}$ 

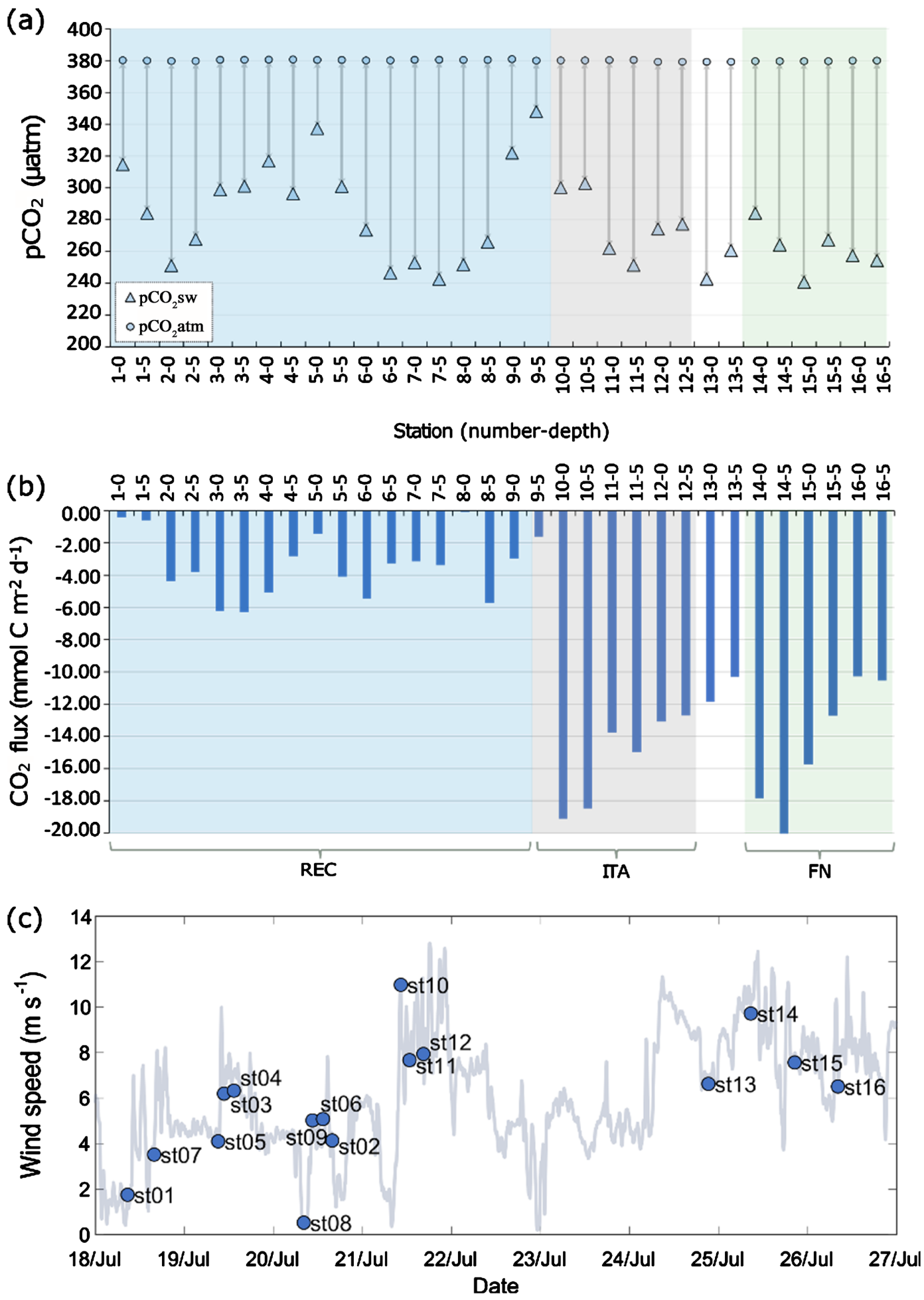

Figure 5. (a) Estimates of atmospheric $p \mathrm{CO}_{2}\left(p \mathrm{CO}_{2 \mathrm{~atm}}\right)$ and calculated $\mathrm{pCO}_{2 \mathrm{sw}}$ ( $\mu$ atm) for surface and subsurface levels $\left(0\right.$ and $5 \mathrm{~m}$ ) at each station within each studied region; (b) $\mathrm{CO}_{2}$ flux estimates (mol $\mathrm{C} \cdot \mathrm{m}^{-2} \cdot$ day $\left.^{-1}\right)$ at the surface in each station within each studied region. Recife (REC), Itamaracá Island and Fernando de Noronha samples are shaded blue, green and red respectively. Levels in Station 13 site are also depicted (no shading). Negative values indicate a sinking flux into the ocean; (c) Wind speed $\left(\mathrm{m} \cdot \mathrm{s}^{-1}\right) \mathrm{re}-$ trieved from the RV Alpha Delphini meteorological station. Dots mark when each station was done as well as the respective wind speed recorded. 
when their entire catchment area is considered (Araujo et al., 2013; Noriega \& Araujo, 2014; Noriega et al., 2015). Nonetheless, local studies investigating the interface between estuary and shelf waters are scarce and the complexity of biological processes taking place in these areas makes the carbonate system variability in the downstream portion of estuarine environments poorly understood. There is also seasonality, which can be an important agent contributing to the variability in the carbonate system (Sutton et al., 2019), adding to the complexity of this area.

Additional uncertainty occurs when $\mathrm{pCO}_{2}$ estimates and other parameters of the carbonate system are derived from linear relationships with, for example, sea surface salinity (SSS). Bonou et al. (2016) emphasized that this is particularly the case when SSS-based $\mathrm{pCO}_{2}$ values are lower than $250 \mu$ atm in regions off the northeastern coast of Brazil as SSS expressions fail to consider the high biological activity observed along the shelf. These deviations might be understood as noise when first analysed altogether in the context of the linear relationships based on large collated datasets. However, by looking closely at the processes that might be driving these deviations, the role of high biological activity becomes evident in differentiating each of these coastal systems, ultimately setting them aside from the general trends. The results presented here suggest that both ITA and FN are systems where biological processes underpinning the carbonate biogeochemistry are very distinct from other areas along the shelf and more offshore. This means that studies involving estimates for the carbonate system parameters relying on SSS in these locations should be considered with caution and factor in biogeochemical processes and seasonal conditions.

The present values for $\mathrm{CO}_{2}$ flux were generally lower than $-12 \mathrm{mmol} \mathrm{C} \cdot \mathrm{m}^{-2} \cdot \mathrm{day}^{-1}$ in ITA and FN. Stations 14 in FN and 10 in ITA, showed the highest influxes $\left(\sim-20 \mathrm{mmol} \mathrm{C} \cdot \mathrm{m}^{-2} \cdot \mathrm{day}^{-1}\right)$. Rain, wind speed and sea roughness are thought to be the main factors responsible for the injection of atmospheric $\mathrm{CO}_{2}$ at these stations, as these contribute to the dissolution of $\mathrm{CO}_{2}$ into seawater by lowering the salinity of the air-sea layer and forming undulations and turbulence. In fact, at the time waters of ITA and FN were sampled at stations 10 and 14, wind speed and sea roughness were the highest registered (wind speeds $>10 \mathrm{~m} \cdot \mathrm{s}^{-1}$ ). Relatively high wind gusts were also observed at stations 15,12 and $11\left(>8 \mathrm{~m} \cdot \mathrm{s}^{-1}\right.$, Figure 5(c)). The observed fluxes result from a water column saturated with atmospheric $\mathrm{CO}_{2}$ being efficiently coupled with biological processes that remove DIN species. Particularly, results suggest that ITA is marked by efficient biological precipitation of calcium carbonate by the calcareous algae matts while the uptake in FN is mainly characterized by ammonium-based productivity and intermittent bursts of moderate production following the entrainment of nutrient-rich water within the thermocline.

An estimated uptake of approximately $9.46 \mathrm{Gt} \mathrm{C} \cdot \mathrm{yr}^{-1}$ was found when all surface in situ values of $\mathrm{CO}_{2}$ flux were averaged within each region and then integrated in space (Table 3 ). This estimate would represent only a $1.7 \%$ offset on the so-called Brazilian Current marginal catchment area outgassing (+0.567 
Table 3. Spatially-averaged fluxes $\left(\overline{\mathrm{CO}_{2} \text { flux }}\right)$ within each region and the estimated annual uptake $\left(\mathrm{CO}_{2}\right.$ uptake) based on their surface area. Pernambuco, Brazil. (Western Tropical South Atlantic, late rainy season, July 2013).

\begin{tabular}{ccccc}
\hline Site & $\begin{array}{c}\overline{\mathbf{C O}_{2} \text { flux }} \\
\left(\mathrm{mmol} \mathrm{C} \cdot \mathrm{m}^{-2} \cdot \mathrm{day}^{-1}\right)\end{array}$ & $\begin{array}{c}\text { Surface area } \\
\left(\mathrm{m}^{2}\right)\end{array}$ & $\begin{array}{c}\overline{\mathbf{C O}_{2} \text { flux }} \\
\left(\mathrm{gC} \cdot \mathrm{m}^{-2} \cdot \mathrm{yr}^{-1}\right)\end{array}$ & $\begin{array}{c}\mathrm{CO}_{2} \text { uptake } \\
\left(\mathrm{gC}_{\mathbf{y r}} \mathbf{y r}^{-1}\right)\end{array}$ \\
\hline REC & -3.58 & $2.8 \times 10^{7}$ & -15.70 & $-4.45 \times 10^{8}$ \\
ITA & -14.90 & $3.6 \times 10^{7}$ & -65.33 & $-2.34 \times 10^{9}$ \\
ST13 & -11.07 & $1.6 \times 10^{-2}$ & -48.55 & $-4.85 \times 10^{-4}$ \\
FN & -15.24 & $1.0 \times 10^{8}$ & -66.81 & $-6.68 \times 10^{9}$ \\
TOTAL & -44.80 & $1.64 \times 10^{8}$ & -196.39 & $-9.46 \times 10^{9}$ \\
\hline
\end{tabular}

TgC. $\mathrm{yr}^{-1}$ ) reported by Laruelle et al. (2014). However minimal this offset might represent when compared to the overall outgassing estimation, it is important to note that this study covered an area over 3000 times smaller than that considered by the referred authors. This highlights how important regional-scale observations are to improving our understanding of the biogeochemical processes which alter the carbonate system. They also contribute to fine tuning large-scale approaches in tropical shelf seas.

It is important to highlight that measurements were based on single observations during the late rainy season, thus they do not represent net fluxes over seasonal cycles and that results were compared to studies based on monthly or seasonally-averaged measurements. This also reinforces the need of further in situ seasonal research to be conducted in the tropical part of the Western South Atlantic to assess whether the patterns observed remain year-round. The need for monitoring efforts addressing the state of Brazilian waters in face of increasing atmospheric $\mathrm{CO}_{2}$ and ocean acidification has been recognized and initiatives are being implemented towards the establishment of a more cohesive and integrative network, able to share information at regional, national, and international stages (Kerr et al., 2016). This study further emphasizes the role of regional-scale studies in the identification of important sites to gain a better understanding of the carbon cycle in shelf seas and long-term shifts in the carbonate system in the equatorial Atlantic off northeastern Brazil.

In FN, even though low Chl-a and DO values indicated the occurrence of remineralization associated with high temperatures, which are factors that induce $\mathrm{CO}_{2}$ outgassing, relatively high $\mathrm{CO}_{2}$ fluxes into the ocean were also detected where typically high seawater temperatures occur throughout the year. de Souza et al. (2013) suggested that, as greater evaporation takes place in FN, surface water salinity tends to increase thus becoming denser. As a result, surface water parcels tend to sink to the base of the thermocline, where they meet lower temperatures and become even denser. This might indicate there are other factors participating in the $\mathrm{CO}_{2}$ sink in the waters surrounding $\mathrm{FN}$ and further investigations as to how this sink is driven must be carried out. Additionally, while this 
study highlights possible effects caused by the North Brazil Undercurrent bifurcation along and off the shelf up to FN's location, observations from Olivier et al. (2021) also highlight the importance of biogeochemistry, biological activity, low-salinity plumes and the role of the North Brazil Current rings in driving variability in productivity, affecting the carbonate system and modulating $\mathrm{CO}_{2}$ fluxes in this portion of the Atlantic.

\section{Conclusion}

Despite being considered homogenous in terms of $\mathrm{CO}_{2}$ fluxes by meso and large-scale modelling studies, this study demonstrates that three Brazilian tropical regions showed specificities in physical and biogeochemical processes as well as trophic conditions that can induce variability in the carbonate system and change $\mathrm{CO}_{2}$ fluxes locally. This shows that parts of the tropical Atlantic can act as $\mathrm{CO}_{2}$ sinks at seasonal scales (in this case considering observations in late rainy season). More studies are needed to determine whether this drawdown is an intermittent pattern or remains year-round. This study also highlights the importance of biological processes in controlling TA and DIC levels in regions of high salinity and low $\mathrm{pCO}_{2 s w}$, besides the influence of freshwater input and SSS in the domain of the South Equatorial Current.

The urbanized estuarine area (REC) is prone to sewage runoffs, eutrophication and intense organic matter decomposition associated with river inputs reaching adjacent areas. REC showed $\mathrm{CO}_{2}$ emission/sequestration tendencies close to atmospheric equilibrium. However, the proximity to the Capibaribe river mouth, an area of low DO values, high freshwater and DIC inputs and elevated remineralization rates, indicate that the carbonate system is prone to shift towards $\mathrm{CO}_{2(\mathrm{aq})}$ formation and outgassing. In contrast, different scenarios were observed in ITA and FN. ITA showed the highest $\mathrm{CO}_{2}$ drawdown flux, which was mediated by shallow, turbulent mixed waters and biogeochemical processes linked to efficient calcification (high $\Omega_{\text {arr }}$ ). The carbonate system in FN was mainly driven by a water column biogeochemically based on oligotrophic characteristics, associated with high $\mathrm{T}$ and $\mathrm{S}$ at the surface and primary production predominantly based on recycled inorganic nitrogen coupled with both enhanced $\mathrm{N}$ fixation and $\mathrm{NH}_{4}^{+}$assimilation. The region is further influenced by Equatorial Atlantic underwater circulation at deeper layers above the thermocline, where nutrient-rich water is brought up and allows for some localized production. However, it is still unclear to what extent these processes can alter seawater biogeochemistry over seasonal timescales, highlighting the need for further studies.

More observations are needed to better understand how these systems can respond to and cope with anthropogenic pressures. ITA has the potential to be an ideal site for the study of carbonate system long-term variability and ocean acidification in the continental shelf of this part of the Equatorial Atlantic, given that 1) calcareous algae banks act as sessile bio-indicators and respond to ocean 
acidification via changes in their calcification rates, 2) ITA is characterized by a relatively shallow, turbulent and well-mixed water column with low variability in $\mathrm{pH}, \mathrm{S}$ and $\mathrm{T}$ with respect to values found offshore, all of which reflect the rapid cascading with respect to changes in atmospheric $\mathrm{CO}_{2}$ and ultimately due to 3) its convenient location with easy access to laboratory facilities. Finally, more regional studies are also needed to promote long-term monitoring efforts and better understand the role of the shelf seas and coastal marine systems in the cycling and sinking of anthropogenic carbon at key regions in the tropical Atlantic.

\section{Acknowledgements}

We thank FAPESP for the financial support provided as part of the Scientific Initiation internship (grant ref. no. 2012/17656-3) and Project CaReCos (grant ref. no. 2011/5058-2). We would like to thank the IOUSP R/V Alpha Delphini crew, who assisted with logistic support and onboard safety, the IOUSP technician $\mathrm{Mr}$ Wilson Natal, who provided the meteorological data, all the collaborators from LABNUT-IOUSP who carried out all the laboratory analyses and organized datasets for T, S, pH, DO and nutrients. We thank our colleagues from the Federal University of Pernambuco (UFPE) for enabling chlorophyll readings. We also thank the anonymous reviewers, who also added positive contributions to the accomplishment of this work.

\section{Conflicts of Interest}

The authors declare no conflicts of interest regarding the publication of this paper.

\section{References}

Almeida, F. F. M. (2007). Ilhas oceânicas brasileiras e suas relações com a tectônica atlântica. Terrae Didatica, 2, 3-18. https://doi.org/10.20396/td.v2i1.8637462

Aminot, A., \& Chaussepied, M. (1983). Manuel des Analyses Chimiques en Milieu Merin (395 p). Centre National Pour L’Explotation des Océans (CNEXO).

Anes, B., Silva, R. J. B., Oliveira, C., \& Camões, M. F. (2018). Uncertainty Evaluation of Alkalinity Measurements on Seawater Samples. Measurement, 129, 395-404. https://doi.org/10.1016/j.measurement.2018.07.042

Araujo, M., Noriega, C., Medeiros, C., Lefèvre, N., Ibanhez, J. S. P., Flores Montes, M. et al. (2019). On the Variability in the $\mathrm{CO}_{2}$ System and Water Productivity in the Western Tropical Atlantic off North and Northeast Brazil. Journal of Marine Systems, 189, 62-77. https://doi.org/10.1016/j.jmarsys.2018.09.008

Araujo, M., Noriega, C., Veleda, D., \& Lefèvre, N. (2013). Nutrient Input and $\mathrm{CO}_{2}$ Flux of a Tropical Coastal Fluvial System with High Population Density in the Northeast Region of Brazil. Journal of Water Resource and Protection, 5, 362-375. https://doi.org/10.4236/jwarp.2013.53A037

Araújo, T. C. M., Seoane, J. C. S., \& Coutinho, P. N. (2004). Geomorfologia da plataforma continental de Pernambuco. In E. Eskinazi-Leça, S. Neumann-Leitão, \& M. F. Costa (Eds.), Oceanografia: um cenário tropical. (pp. 39-58). Bagaço.

Arhan, M., Mercier, H., Bourlès, B., \& Gouriou, Y. (1998). Hydrographic Sections across 
the Atlantic at $7^{\circ} 30 \mathrm{~N}$ and $4^{\circ} 30 \mathrm{~S}$. Deep Sea Research Part I: Oceanographic Research Papers, 45, 829-872. https://doi.org/10.1016/S0967-0637(98)00001-6

Bates, N. R. (2007). Interannual Variability of the Oceanic $\mathrm{CO}_{2}$ Sink in the Subtropical Gyre of the North Atlantic Ocean over the Last 2 Decades. Journal of Geophysical Research: Oceans, 112, C09013. https://doi.org/10.1029/2006JC003759

Bates, N. R., Astor, Y. M., Church, M. J., Currie, K., Dore, J. E., González-Dávila, M. et al. (2014). A Time-Series View of Changing Surface Ocean Chemistry Due to Ocean Uptake of Anthropogenic $\mathrm{CO}_{2}$ and Ocean Acidification. Oceanography, 27, 126-141. https://doi.org/10.5670/oceanog.2014.16

Bonou, F. K., Noriega, C., Lefèvre, N., \& Araujo, M. (2016). Distribution of $\mathrm{CO}_{2}$ Parameters in the Western Tropical Atlantic Ocean. Dynamics of Atmospheres and Oceans, 73, 47-60. https://doi.org/10.1016/j.dynatmoce.2015.12.001

Braga, E. S. (1997a). Determinação automática de nitrato. In: A. R. Wagener, \& R. Carreira (Org.). Métodos analíticos de referência em Oceanografia Química (Vol. 1, pp. 31-35). REVIZEE, MMA, SMA.

Braga, E. S. (1997b). Determinação automática de nitrato. In: A. R. Wagener, \& R. Carreira (Org.). Métodos analíticos de referência em Oceanografia Química (Vol. 1, pp. 27-29). REVIZEE, MMA, SMA.

Braga, E. S., Berbel, G. B. B., \& Chiozzini, V. G. (2018a). Dissolved Organic Matter (C, N, $\mathrm{P}$ ) on the Pernambuco Coast and Fernando de Noronha archipelago (Tropical Zone of Western South Atlantic, Brazil)-A Contribution to the Evaluation of Environmental Impact. Brazilian Journal of Oceanography, 66, 30-46. https://doi.org/10.1590/s1679-87592018147906601

Braga, E. S., Chiozzini, V. G., \& Berbel, G. B. B. (2018b). Oligotrophic Water Conditions Associated with Organic Matter Regeneration Support Life and Indicate Pollution on the Western Side of Fernando de Noronha Island-NE, Brazil $\left(3^{\circ} \mathrm{S}\right)$. Brazilian Journal of Oceanography, 66, 73-90. https://doi.org/10.1590/s1679-87592018148306601

Broecker, W. S., Takahashi, T., Simpson, H., \& Peng, T.-H. (1979). Fate of Fossil Fuel Carbon Dioxide and the Global Carbon Budget. Science, 206, 409-418. https://doi.org/10.1126/science.206.4417.409

Capone, D. G., Burns, J. A., Montoya, J. P., Subramaniam, A., Mahaffey, C., Gunderson, T. et al. (2005). Nitrogen Fixation by Trichodesmium spp.: An Important Source of New Nitrogen to the Tropical and Subtropical North Atlantic Ocean. Global Biogeochemical Cycles, 19, GB2024. https://doi.org/10.1029/2004GB002331

Cooley, S. R., \& Yager, P. L. (2006). Physical and Biological Contributions to the Western Tropical North Atlantic Ocean Carbon Sink Formed by the Amazon River Plume. Journal of Geophysical Research: Oceans, 111, C08018.

https://doi.org/10.1029/2005JC002954

Cooley, S., Coles, V., Subramaniam, A., \& Yager, P. (2007). Seasonal Variations in the Amazon Plume-Related Atmospheric Carbon Sink. Global Biogeochemical Cycles, 21, GB3014. https://doi.org/10.1029/2006GB002831

Cordeiro, T. A., Brandini, F. P., Rosa, R. S., \& Sassi, R. (2013). Deep Chlorophyll Maximum in Western Equatorial Atlantic-How Does It Interact with Islands Slopes and Seamounts. Marine Science, 3, 30-37. https://doi.org/10.5923/j.ms.20130301.03

CPRH-PE (2012). Relatório de Bacias Hidrográficas. http://www.cprh.pe.gov.br/ARQUIVOS ANEXO/K Relat12-CB.pdf

de Souza, C. S., da Luz, J. A. G., Macedo, S., Flores Montes, M. J., \& Mafalda, P. (2013). Chlorophyll a and Nutrient Distribution around Seamounts and Islands of the Tropical 
South-Western Atlantic. Marine and Freshwater Research, 64, 168-184. https://doi.org/10.1071/MF12075

Dickson, A. G. (1990). Thermodynamics of the Dissociation of Boric Acid in Synthetic Seawater from 273.15 to 318.15 K. Deep Sea Research Part A. Oceanographic Research Papers, 37, 755-766. https://doi.org/10.1016/0198-0149(90)90004-F

Dickson, A. G., Sabine, C. L., \& Christian, J. R. (2007). Guide to Best Practices for Ocean $\mathrm{CO}_{2}$ Measurements. North Pacific Marine Science Organization.

Dlugokencky, E., Lang, P., Masarie, K., Crotwell, A., \& Crotwell, M. (2015). Atmospheric Carbon Dioxide Dry Air Mole Fractions from the NOAA ESRL Carbon Cycle Cooperative Global Air Sampling Network, 1968-2014. NOAA ESRL Global Monitoring Division.

Doney, S. C., Balch, W. M., Fabry, V. J., \& Feely, R. A. (2009). Ocean Acidification: A Critical Emerging Problem for the Ocean Sciences. Oceanography, 22, 16-25. https://doi.org/10.5670/oceanog.2009.93

Egleston, E. S., Sabine, C. L., \& Morel, F. M. M. (2010). Revelle Revisited: Buffer Factors that Quantify the Response of Ocean Chemistry to Changes in DIC and Alkalinity. Global Biogeochemical Cycles, 24, GB1002. https://doi.org/10.1029/2008GB003407

Flores Montes, M. J., Paulo, J., Nascimento Filho, G., Gaspar, F., Feitosa, F. A., Santos, A. et al. (2011). The Trophic Status of an Urban Estuarine Complex in Northeast Brazil. Journal of Coastal Research, 64, 408-411.

Friedlingstein, P., Jones, M., O’sullivan, M., Andrew, R., Hauck, J., Peters, G. et al. (2019). Global Carbon Budget 2019. Earth System Science Data, 11, 1783-1838.

https://doi.org/10.5194/essd-11-1783-2019

Gibbard, S., Caldeira, K., Bala, G., Phillips, T. J., \& Wickett, M. (2005). Climate Effects of Global Land Cover Change. Geophysical Research Letters, 32, L23705. https://doi.org/10.1029/2005GL024550

Gomes, P. O., Gomes, B. S., Palma, J., Jinno, K., \& De Souza, J. M. (2000). Ocean-Continent Transition and Tectonic Framework of the Oceanic Crust at the Continental Margin off NE Brazil: Results of LEPLAC Project. Geophysical Monograph-American Geophysical Union, 115, 261-292. https://doi.org/10.1029/GM115p0261

Goyet, C., Adams, R., \& Eischeid, G. (1998). Observations of the $\mathrm{CO}_{2}$ System Properties in the Tropical Atlantic Ocean. Marine Chemistry, 60, 49-61.

https://doi.org/10.1016/S0304-4203(97)00081-9

Grasshoff, K., Kremling, K., \& Erhardt, M. (1999). Methods of Seawater Analysis (3rd ed., 600 p). Wiley-VCH Verlag. https://doi.org/10.1002/9783527613984

Gruber, N., \& Sarmiento, J. L. (1997). Global Patterns of Marine Nitrogen Fixation and Denitrification. Global Biogeochemical Cycles, 11, 235-266. https://doi.org/10.1029/97GB00077

Gruber, N., Gloor, M., Mikaloff Fletcher, S. E., Doney, S. C., Dutkiewicz, S., Follows, M. J. et al. (2009). Oceanic Sources, Sinks, and Transport of Atmospheric $\mathrm{CO}_{2}$. Global Biogeochemical Cycles, 23, GB1005. https://doi.org/10.1029/2008GB003349

Guo, X., Cai, W.-J., Zhai, W., Dai, M., Wang, Y., \& Chen, B. (2008). Seasonal Variations in the Inorganic Carbon System in the Pearl River (Zhujiang) Estuary. Continental Shelf Research, 28, 1424-1434. https://doi.org/10.1016/j.csr.2007.07.011

Hutchins, D., Fu, F.-X., Zhang, Y., Warner, M., Feng, Y., Portune, K. et al. (2007). $\mathrm{CO}_{2}$ control of Trichodesmium $\mathrm{N}_{2}$ Fixation, Photosynthesis, Growth Rates, and Elemental Ratios: Implications for Past, Present, and Future Ocean Biogeochemistry. Limnology and Oceanography, 52, 1293-1304. https://doi.org/10.4319/lo.2007.52.4.1293 
IBGE (2015a). Fernando de Noronha/Pernambuco. Instituto Brasileiro de Geografia e Estatística. http://cod.ibge.gov.br/FTA

IBGE (2015b). Ilha de Itamaracá/ Pernambuco. Instituto Brasileiro de Geografia e Estatística. http://cod.ibge.gov.br/CWI

IBGE (2015c). Recife/Pernambuco. Instituto Brasileiro de Geografia e Estatística. http://cod.ibge.gov.br/BDM

IPCC (2014). Summary for Policymakers. In C. B. Field et al. (Ed.), Climate Change 2014: Impacts, Adaptation, and Vulnerability. Part A: Global and Sectoral Aspects. Contribution of Working Group II to the Fifth Assessment Report of the Intergovernmental Panel on Climate Change (pp. 1-32).

Jales, M. C., Feitosa, F. A. N., Koening, M. L., Montes, M. J. F., Araújo Filho, M. C., \& Silva, R. A. (2015). Phytoplankton Biomass Dynamics and Environmental Variables around the Rocas Atoll Biological Reserve, South Atlantic. Brazilian Journal of Oceanography, 63, 443-454. https://doi.org/10.1590/S1679-87592015093906304

Kerr, R., da Cunha, L. C., Kikuchi, R. K. P., Horta, P. A., Ito, R. G., Müller, M. N. et al. (2016). The Western South Atlantic Ocean in a High- $\mathrm{CO}_{2}$ World: Current Measurement Capabilities and Perspectives. Environmental Management, 57, 740-752. https://doi.org/10.1007/s00267-015-0630-x

Körtzinger, A. (2003). A Significant $\mathrm{CO}_{2}$ Sink in the Tropical Atlantic Ocean Associated with the Amazon River Plume. Geophysical Research Letters, 30, 2287. https://doi.org/10.1029/2003GL018841

Landschützer, P., Gruber, N., Bakker, D. C., \& Schuster, U. (2014). Recent Variability of the Global Ocean Carbon Sink. Global Biogeochemical Cycles, 28, 927-949. https://doi.org/10.1002/2014GB004853

Laruelle, G. G., Lauerwald, R., Pfeil, B., \& Regnier, P. (2014). Regionalized Global Budget of the $\mathrm{CO}_{2}$ Exchange at the Air-Water Interface in Continental Shelf Seas. Global Biogeochemical Cycles, 28, 1199-1214. https://doi.org/10.1002/2014GB004832

Le Quéré, C., Moriarty, R., Andrew, R. M., Canadell, J. G., Sitch, S., Korsbakken, J. I. et al. (2015). Global Carbon Budget 2015. Earth System Science Data, 7, 349-396. https://doi.org/10.5194/essd-7-349-2015

Lee, K., Millero, F. J., Byrne, R. H., Feely, R. A., \& Wanninkhof, R. (2000). The Recommended Dissociation Constants for Carbonic Acid in Seawater. Geophysical Research Letters, 27, 229-232. https://doi.org/10.1029/1999GL002345

Lefévre, N., Diverrés, D., \& Gallois, F. (2017). Origin of $\mathrm{CO}_{2}$ Undersaturation in the Western Tropical Atlantic. Tellus B: Chemical and Physical Meteorology, 62, 595-607. https://doi.org/10.1111/j.1600-0889.2010.00475.x

Lumpkin, R., \& Garzoli, S. L. (2005). Near-Surface Circulation in the Tropical Atlantic Ocean. Deep Sea Research Part I: Oceanographic Research Papers, 52, 495-518. https://doi.org/10.1016/j.dsr.2004.09.001

Marin, F. de O. (2009). A Subcorrente Norte do Brasil ao largo da Costa do Nordeste. Universidade de São Paulo.

Matheus, Z., Francini-Filho, R. B., Pereira-Filho, G. H., Moraes, F. C., Moura, R. L., et al. (2019). Benthic Reef Assemblages of the Fernando de Noronha Archipelago, Tropical South-West Atlantic: Effects of Depth, Wave Exposure and Cross-Shelf Positioning. PLoS ONE, 14, e0210664. https://doi.org/10.1371/journal.pone.0210664

Millero, F. J. (2010). Carbonate Constants for Estuarine Waters. Marine and Freshwater Research, 61, 139-142. https://doi.org/10.1071/MF09254

Moore, C. M., Mills, M. M., Achterberg, E. P., Geider, R. J., LaRoche, J., Lucas, M. I. et al. 
(2009). Large-Scale Distribution of Atlantic Nitrogen Fixation Controlled by Iron Availability. Nature Geoscience, 2, 867-871. https://doi.org/10.1038/ngeo667

Noriega, C., \& Araujo, M. (2014). Carbon Dioxide Emissions from Estuaries of Northern and Northeastern Brazil. Scientific Reports, 4, Article No. 6164. https://doi.org/10.1038/srep06164

Noriega, C., Araujo, M., Lefevre, N., Montes, M. F., Gaspar, F., \& Veleda, D. (2015). Spatial and Temporal Variability of $\mathrm{CO}_{2}$ Fluxes in Tropical Estuarine Systems near Areas of High Population Density in Brazil. Regional Environmental Change, 15, 619-630. https://doi.org/10.1007/s10113-014-0671-3

Olivier, L., Boutin, J., Reverdin, G., Lefèvre, N., Landschützer, P., Speich, S. et al. (2021). Impact of North Brazil Current Rings on Air-Sea $\mathrm{CO}_{2}$ Flux Variability in Winter 2020. Biogeosciences Discussions, 1-30. https://doi.org/10.5194/bg-2021-269

Oudot, C., Ternon, J.-F., \& Lecomte, J. (1995). Measurements of Atmospheric and Oceanic $\mathrm{CO}_{2}$ in the Tropical Atlantic: 10 Years after the 1982-1984 FOCAL Cruises. Tellus B: Chemical and Physical Meteorology, 47, 70-85. https://doi.org/10.3402/tellusb.v47i1-2.16032

Queiroz, A. R., Montes, M. F., Castro Melo, P. A. M., Silva, R. A., \& Koening, M. L. (2015). Vertical and Horizontal Distribution of Phytoplankton around an Oceanic Archipelago of the Equatorial Atlantic. Marine Biodiversity Records, 8, e155. https://doi.org/10.1017/S175526721500130X

Riebesell, U., Zondervan, I., Rost, B., Tortell, P. D., Zeebe, R. E., \& Morel, F. M. (2000). Reduced Calcification of Marine Plankton in Response to Increased Atmospheric $\mathrm{CO}_{2}$. Nature, 407, 364-367. https://doi.org/10.1038/35030078

Riul, P., Targino, C. H., Farias, J. D. N., Visscher, P. T., \& Horta, P. A. (2008). Decrease in Lithothamnion sp. (Rhodophyta) Primary Production Due to the Deposition of a Thin Sediment Layer. Journal of the Marine Biological Association of the United Kingdom, 88, 17-19. https://doi.org/10.1017/S0025315408000258

Robbins, L., Hansen, M., Kleypas, J., \& Meylan, S. (2010). CO2calc: A User-Friendly Seawater Carbon Calculator for Windows, Mac OS X, and iOS (iPhone). Open-File Report 2010-1280. USGS. https://pubs.usgs.gov/of/2010/1280/pdf/ofr 2010-1280.pdf

Rockström, J., Steffen, W., Noone, K., Persson, Å., Chapin III, F. S., Lambin, E. F. et al. (2009). A Safe Operating Space for Humanity. Nature, 461, 472-475.

https://doi.org/10.1038/461472a

Santiago, M. F., Silva-Cunha, M. G. G., Neumann-Leitão, S., Costa, K. M. P. Palmeira, G. C. B., Neto, P. et al. (2010). Phytoplankton Dynamics in a Highly Eutrophic Estuary in Tropical Brazil. Brazilian Journal of Oceanography, 58, 189-205. https://doi.org/10.1590/S1679-87592010000300002

Schott, F. A., Brandt, P., Hamann, M., Fischer, J., \& Stramma, L. (2002). On the Boundary Flow off Brazil at $5-10^{\circ} \mathrm{S}$ and Its Connection to the Interior Tropical Atlantic. Geophysical Research Letters, 29, 21-1-21-4. https://doi.org/10.1029/2002GL014786

Schott, F. A., Dengler, M., Zantopp, R., Stramma, L., Fischer, J., \& Brandt, P. (2005). The Shallow and Deep Western Boundary Circulation of the South Atlantic at $5^{\circ}-11^{\circ} \mathrm{S}$. Journal of Physical Oceanography, 35, 2031-2053. https://doi.org/10.1175/JPO2813.1

Schuster, U., \& Gruber, N. (2012). Atlantic and Arctic Sea-Air $\mathrm{CO}_{2}$ Fluxes, 1990-2009. Biogeosciences Discussions, 9, 10669-10724.

Silva, B. J., Gaspar, F. L., Tyaquiçã, P., Lefèvre, N., \& Flores Montes, M. J. (2019). Carbon Chemistry Variability around a Tropical Archipelago. Marine and Freshwater Research, 70, 767-780. https://doi.org/10.1071/MF18011

Solorzano, L. (1969). Determination of Ammonia in Natural Waters by the Phenolhy- 
pochlorite Method. Limnology and Oceanography, 14, 799-801. https://doi.org/10.4319/lo.1969.14.5.0799

Stramma, L., \& Schott, F. (1999). The Mean Flow Field of the Tropical Atlantic Ocean. Deep Sea Research Part II: Topical Studies in Oceanography, 46, 279-303. https://doi.org/10.1016/S0967-0645(98)00109-X

Strickland, J. D. H., \& Parsons, T. R. (1972). A Parctical Handbook of Seawater Analysis. Bulletin 167 (2nd ed., 328 p.). Fisheries Research Board of Canada.

Sutton, A. J., Feely, R. A., Maenner-Jones, S., Musielwicz, S., Osborne, J., Dietrich, C. et al. (2019). Autonomous Seawater $p \mathrm{CO}_{2}$ and $\mathrm{pH}$ Time Series from 40 Surface Buoys and the Emergence of Anthropogenic Trends. Earth System Science Data, 11, 421-439. https://doi.org/10.5194/essd-11-421-2019

Takahashi, T., Sutherland, S. C., Sweeney, C., Poisson, A., Metzl, N., Tilbrook, B. et al. (2002). Global Sea-Air $\mathrm{CO}_{2}$ Flux Based on Climatological Surface Ocean $p \mathrm{CO}_{2}$, and Seasonal Biological and Temperature Effects. Deep Sea Research Part II: Topical Studies in Oceanography, 49, 1601-1622. https://doi.org/10.1016/S0967-0645(02)00003-6

Takahashi, T., Sutherland, S. C., Wanninkhof, R., Sweeney, C., Feely, R. A., Chipman, D. W. et al. (2009). Climatological Mean and Decadal Change in Surface Ocean $p \mathrm{CO}_{2}$, and Net Sea-Air $\mathrm{CO}_{2}$ Flux over the Global Oceans. Deep Sea Research Part II: Topical Studies in Oceanography, 56, 554-577. https://doi.org/10.1016/j.dsr2.2008.12.009

Ternon, J.-F., Oudot, C., Dessier, A., \& Diverres, D. (2000). A Seasonal Tropical Sink for Atmospheric $\mathrm{CO}_{2}$ in the Atlantic Ocean: The Role of the Amazon River Discharge. Marine Chemistry, 68, 183-201. https://doi.org/10.1016/S0304-4203(99)00077-8

Tréguer, P., \& Le Corre, P. (1975). Manuel d'analyse des sels nutritifs dans l'eau de mer. Laboratoire d'Océanographie Chimique, Université de Bretagne Occidentale.

UNESCO (1981). The Practical Salinity Scale 1978 and the International Equation of State of Seawater 1980. In Tenth Report of the Joint Panel on Oceanographic Tables and Standards (JPOTS) (25 p). UNESCO Technical Papers in Marine Science No. 36.

Ussiri, D. A. N., \& Lal, R. (2017). The Global Carbon Inventory. In Carbon Sequestration for Climate Change Mitigation and Adaptation (pp. 77-102). Springer International Publishing. https://doi.org/10.1007/978-3-319-53845-7 4

Villas-Bôas, A. B., Figueiredo, M. O., \& Villaça, R. C. (2005). Colonization and Growth of Crustose Coralline Algae (Corallinales, Rhodophyta) on the Rocas Atoll. Brazilian Journal of Oceanography, 53, 147-156. https://doi.org/10.1590/S1679-87592005000200005

Weiss, R., \& Price, B. (1980). Nitrous Oxide Solubility in Water and Seawater. Marine Chemistry, 8, 347-359. https://doi.org/10.1016/0304-4203(80)90024-9

Winn, C. D., Li, Y.-H., Mackenzie, F. T., \& Karl, D. M. (1998). Rising Surface Ocean Dissolved Inorganic Carbon at the Hawaii Ocean Time-Series Site. Marine Chemistry, 60, 33-47. https://doi.org/10.1016/S0304-4203(97)00085-6

Wolf-Gladrow, D. A., Zeebe, R. E., Klaas, C., Körtzinger, A., \& Dickson, A. G. (2007). Total Alkalinity: The Explicit Conservative Expression and Its Application to Biogeochemical Processes. Marine Chemistry, 106, 287-300.

https://doi.org/10.1016/j.marchem.2007.01.006

Zhai, W., Dai, M., \& Guo, X. (2007). Carbonate System and $\mathrm{CO}_{2}$ Degassing Fluxes in the Inner Estuary of Changjiang (Yangtze) River, China. Marine Chemistry, 107, 342-356. https://doi.org/10.1016/j.marchem.2007.02.011 